\title{
Impacts of aviation fuel sulfur content on climate and human health
}

\author{
Zarashpe Z. Kapadia ${ }^{1,2}$, Dominick V. Spracklen ${ }^{2}$, Steve R. Arnold ${ }^{2}$, Duncan J. Borman ${ }^{3}$, Graham W. Mann ${ }^{2,4}$, \\ Kirsty J. Pringle ${ }^{2}$, Sarah A. Monks ${ }^{2, a, b}$, Carly L. Reddington ${ }^{2}$, François Benduhn ${ }^{5}$, Alexandru Rap ${ }^{2}$, \\ Catherine E. Scott ${ }^{2}$, Edward W. Butt ${ }^{2}$, and Masaru Yoshioka ${ }^{2}$ \\ ${ }^{1}$ Doctoral Training Centre in Low Carbon Technologies, Energy Research Institute, School of Process Environmental and \\ Materials Engineering, University of Leeds, Leeds, UK \\ ${ }^{2}$ Institute for Climate and Atmospheric Science, School of Earth and Environment, University of Leeds, Leeds, UK \\ ${ }^{3}$ Centre for Computational Fluid Dynamics, School of Civil Engineering, University of Leeds, Leeds, UK \\ ${ }^{4}$ National Centre for Atmospheric Science, School of Earth and Environment, University of Leeds, Leeds, UK \\ ${ }^{5}$ Institute for Advanced Sustainability Studies, Potsdam, Germany \\ ${ }^{a}$ now at: Cooperative Institute for Research in Environmental Sciences, University of Colorado, Boulder, \\ Colorado, USA \\ ${ }^{\mathrm{b}}$ now at: Chemical Sciences Division, NOAA Earth System Research Laboratory, Boulder, Colorado, USA
}

Correspondence to: Zarashpe Z. Kapadia (pm08zzk@ leeds.ac.uk)

Received: 5 May 2015 - Published in Atmos. Chem. Phys. Discuss.: 10 July 2015

Revised: 28 May 2016 - Accepted: 7 June 2016 - Published: 24 August 2016

\begin{abstract}
Aviation emissions impact both air quality and climate. Using a coupled tropospheric chemistry-aerosol microphysics model we investigate the effects of varying aviation fuel sulfur content (FSC) on premature mortality from longterm exposure to aviation-sourced $\mathrm{PM}_{2.5}$ (particulate matter with a dry diameter of $<2.5 \mu \mathrm{m}$ ) and on the global radiation budget due to changes in aerosol and tropospheric ozone. We estimate that present-day non- $\mathrm{CO}_{2}$ aviation emissions with a typical FSC of 600 ppm result in $~ 3600$ [95\% CI: 1310-5890] annual premature mortalities globally due to increases in cases of cardiopulmonary disease and lung cancer, resulting from increased surface $\mathrm{PM}_{2.5}$ concentrations. We quantify the global annual mean combined radiative effect $\left(\mathrm{RE}_{\mathrm{comb}}\right)$ of non- $\mathrm{CO}_{2}$ aviation emissions as $-13.3 \mathrm{~mW} \mathrm{~m}^{-2}$; from increases in aerosols (direct radiative effect and cloud albedo effect) and tropospheric ozone.

Ultra-low sulfur jet fuel (ULSJ; FSC $=15 \mathrm{ppm}$ ) has been proposed as an option to reduce the adverse health impacts of aviation-induced $\mathrm{PM}_{2.5}$. We calculate that swapping the global aviation fleet to ULSJ fuel would reduce the global aviation-induced mortality rate by $\sim 620$ [95 \% CI: 230-1020] mortalities $\mathrm{a}^{-1}$ and increase $\mathrm{RE}_{\text {comb }}$ by $+7.0 \mathrm{~mW} \mathrm{~m}^{-2}$.

We explore the impact of varying aviation FSC between 0 and $6000 \mathrm{ppm}$. Increasing FSC increases aviation-induced
\end{abstract}

mortality, while enhancing climate cooling through increasing the aerosol cloud albedo effect (CAE). We explore the relationship between the injection altitude of aviation emissions and the resulting climate and air quality impacts. Compared to the standard aviation emissions distribution, releasing aviation emissions at the ground increases global aviation-induced mortality and produces a net warming effect, primarily through a reduced CAE. Aviation emissions injected at the surface are 5 times less effective at forming cloud condensation nuclei, reducing the aviation-induced CAE by a factor of 10. Applying high FSCs at aviation cruise altitudes combined with ULSJ fuel at lower altitudes results in reduced aviation-induced mortality and increased negative $\mathrm{RE}$ compared to the baseline aviation scenario.

\section{Introduction}

Aviation is the fastest growing form of transport (Eyring et al., 2010; Lee et al., 2010; Uherek et al., 2010), with a projected growth in passenger air traffic of $5 \% \mathrm{yr}^{-1}$ until 2030 (Barrett et al., 2012; ICAO, 2013), and a projected near doubling of emissions by 2025, relative to 2005 (Eyers et al., 2004). These emissions, and changes to them, have both cli- 
mate and air quality impacts (Lee et al., 2009; Barrett et al., 2010, 2012; Woody et al., 2011).

Aviation emits a range of gas-phase and aerosol pollutants that can influence climate. Emissions of carbon dioxide $\left(\mathrm{CO}_{2}\right)$ from aviation warm the climate (Lee et al., 2009, 2010). Emissions of nitrogen oxides $\left(\mathrm{NO}_{x}\right)$ warm the climate through tropospheric ozone $\left(\mathrm{O}_{3}\right)$ formation, which acts as a greenhouse gas, and cool climate via a decrease in the lifetime of the well-mixed greenhouse gas methane $\left(\mathrm{CH}_{4}\right)$ through increases in the $\mathrm{OH}$ radical (Holmes et al., 2011; Myhre et al., 2011). Sulfate and nitrate aerosols, formed from aviation sulfur dioxide $\left(\mathrm{SO}_{2}\right)$ and $\mathrm{NO}_{x}$ emissions and through altered atmospheric oxidants, lead to a cooling (Unger, 2011; Righi et al., 2013; Dessens et al., 2014), and black carbon (BC) emissions result in a warming (Balkanski et al., 2010). Additionally, the formation of persistent linear contrails and contrail-cirrus from aircraft leads to warming (Lee et al., 2010; Rap et al., 2010; Burkhardt and Karcher, 2011). Overall, aviation emissions are thought to have a warming impact on climate, with net radiative forcing (RF) estimated as $+55 \mathrm{~mW} \mathrm{~m}^{-2}$ (excluding cirrus cloud enhancement) (Lee et al., 2010).

Previous studies have separately assessed the impacts of aviation through different atmospheric species. Short-term $\mathrm{O}_{3}$ has been estimated to have a radiative effect ranging between 6 and $36.5 \mathrm{~mW} \mathrm{~m}^{-2}$ (Sausen et al., 2005; Köhler et al., 2008; Hoor et al., 2009; Lee et al., 2009; Holmes et al., 2011; Myhre et al., 2011; Unger, 2011; Frömming et al., 2012; Skowron et al., 2013; Unger et al., 2013; Khodayari et al., 2014; Brasseur et al., 2016). The aerosol direct effect is highly uncertain $\left[-28\right.$ to $\left.+20 \mathrm{~mW} \mathrm{~m}^{-2}\right]$ (Righi et al., 2013), with the direct aerosol effects for sulfate ranging between -0.9 and $-7 \mathrm{~mW} \mathrm{~m}^{-2}$ (Sausen et al., 2005; Fuglestvedt et al., 2008; Lee et al., 2009; Balkanski et al., 2010; Unger, 2011; Gettelman and Chen, 2013; Brasseur et al., 2016), nitrate ranging between -4 and $-7 \mathrm{~mW} \mathrm{~m}^{-2}$ (Unger et al., 2013; Brasseur et al., 2016), BC ranging between 0.1 and $0.3 \mathrm{~mW} \mathrm{~m}^{-2}$ (Sausen et al., 2005; Fuglestvedt et al., 2008; Lee et al., 2009; Balkanski et al., 2010; Unger, 2011; Gettelman and Chen, 2013; Unger et al., 2013; Brasseur et al., 2016), and for organic carbon (OC) ranging between -0.67 and $-0.01 \mathrm{~mW} \mathrm{~m}^{-2}$ (Sausen et al., 2005; Fuglestvedt et al., 2008; Lee et al., 2009; Balkanski et al., 2010; Unger, 2011; Gettelman and Chen, 2013; Unger et al., 2013). Few studies estimate the aerosol cloud albedo effect (aCAE) from aviation: Righi et al. (2013) assessed the aCAE to be $-15.4 \pm 10.6 \mathrm{~mW} \mathrm{~m}^{-2}$ while Gettelman and Chen (2013) estimate $-21 \pm 11 \mathrm{~mW} \mathrm{~m}^{-2}$.

Aviation emissions can increase atmospheric concentrations of fine particulate matter with a dry diameter of $<2.5 \mu \mathrm{m}\left(\mathrm{PM}_{2.5}\right)$. Short-term exposure to $\mathrm{PM}_{2.5}$ can exacerbate existing respiratory and cardiovascular ailments, while long-term exposure can result in chronic respiratory and cardiovascular diseases, lung cancer, chronic changes in physiological functions and mortality (Pope et al., 2002; World
Health Organisation, 2003; Ostro, 2004). In the US aviation emissions are estimated to lead to adverse health effects in $\sim 11000$ people (ranging from mortality, respiratory ailments and hospital admissions due to exacerbated respiratory conditions) and $\sim 23000$ work loss days per annum (Ratliff et al., 2009). Landing and take-off aviation emissions increase $\mathrm{PM}_{2.5}$ concentrations, particularly around airports (Woody et al., 2011), increasing US mortality rates by $\sim 160$ per annum.

Previous studies have estimated the number of premature mortalities due to exposure to pollution resulting from aviation emissions. Barrett et al. $(2012,2010)$ used the methodology of Ostro (2004) to estimate that aviation emissions are responsible for $\sim 10000$ premature mortalities $\mathrm{a}^{-1}$ due to increases in cases of cardiopulmonary disease and lung cancer. Yim et al. (2015) using the same methodology but with the inclusion of the Rapid Dispersion Code (RDC) to simulate the local air quality impacts of aircraft ground level emissions estimated 13920 (95\% CI: 7220-20 880) mortalities $\mathrm{a}^{-1}$. Morita et al. (2014), using the integrated exposure-response (IER) model from Burnett et al. (2014) to derive relative risk (RR), estimate that aviation results in 405 (95\% CI: 182-648) mortalities $\mathrm{a}^{-1}$ due to increases in cases of lung cancer, stroke, ischemic heart disease, trachea, bronchus, and chronic obstructive pulmonary disease. Jacobson et al. (2013) estimate 310 (95\% CI: -400 to 4300) mortalities $\mathrm{a}^{-1}$ from aviation emissions due to cardiovascular effects. Taking these studies in account, the different methodologies applied and modes of mortality investigated aviation is estimated to be responsible for between 310 and 13920 mortalities $\mathrm{a}^{-1}$.

The introduction of cleaner fuels and pollution control technologies can improve ambient air quality and reduce adverse health effects of fossil fuel combustion (World Health Organisation, 2005). One proposed solution to reduce the adverse health effects of aviation-induced $\mathrm{PM}_{2.5}$ is the use of ultra-low sulfur jet fuel (ULSJ), reducing the formation of sulfate aerosol (Barrett et al., 2012, 2010; Ratliff et al., 2009; Hileman and Stratton, 2014). ULSJ fuels typically have a fuel sulfur content (FSC) of $15 \mathrm{ppm}$, compared with an FSC of between 550 and $750 \mathrm{ppm}$ in standard aviation fuels (Barrett et al., 2012). The current global regulatory standard for aviation fuel is a maximum FSC of $3000 \mathrm{ppm}$ (Ministry of Defence, 2011; ASTM International, 2012).

Despite the potential for decreased emission of $\mathrm{SO}_{2}$, application of ULSJ fuel will not completely remove the impacts of aviation on $\mathrm{PM}_{2.5}$. It is estimated that over a half of aviation-attributable surface-level sulfate is associated with oxidation of non-aviation $\mathrm{SO}_{2}$ by $\mathrm{OH}$ produced from aviation $\mathrm{NO}_{x}$ emissions, and not directly produced from aviationemitted $\mathrm{SO}_{2}$ (Barrett et al., 2010). Therefore, even a completely desulfurized global aviation fleet would likely contribute a net source of sulfate $\mathrm{PM}_{2.5}$. Nevertheless, previous work has shown that the use of ULSJ fuel reduces global aviation-induced $\mathrm{PM}_{2.5}$ by $\sim 23 \%$, annually avoid- 
ing 2300 (95\% CI: 890-4200) mortalities (Barrett et al., 2012).

Altering the sulfur content of aviation fuel also modifies the net climate impact of aviation emissions. A reduction in fuel sulfur content reduces the formation of cooling sulfate aerosols (Unger, 2011; Barrett et al., 2012), increasing the net warming effect of aviation emissions. The roles of sulfate both in climate cooling and in increasing surface $\mathrm{PM}_{2.5}$ concentrations mean that policy makers must consider both health and climate when considering effects from potential reductions in sulfur emissions from a given emissions sector (Fiore et al., 2012).

In this study, we investigate the impacts of changes in the sulfur content of aviation fuel on climate and human health. A coupled tropospheric chemistry-aerosol microphysics model is used to quantify global atmospheric responses in aerosol and $\mathrm{O}_{3}$ to varying FSC scenarios. Radiative effects due to changes in tropospheric $\mathrm{O}_{3}$ and aerosols are calculated using a radiative transfer model, while the impacts of changes in surface $\mathrm{PM}_{2.5}$ on human health are estimated using concentration response functions. Using a coupled tropospheric chemistry-aerosol microphysics model that includes nitrate aerosol allows us to assess the impacts of nitrate and aerosol indirect effects in addition to the ozone and aerosol direct effects that have been more routinely calculated.

\section{Methods}

\subsection{Coupled chemistry-aerosol microphysics model}

\subsubsection{Model description}

We use GLOMAP-mode (Mann et al., 2010), embedded within the 3-D off-line Eulerian chemical transport model TOMCAT (Arnold et al., 2005; Chipperfield, 2006). Meteorology (wind, temperature and humidity) and largescale transport is specified from interpolation of 6-hourly European Centre for Medium Range Weather Forecasts (ECMWF) reanalysis (ERA-40) fields (Chipperfield, 2006; Mann et al., 2010). Cloud fraction and cloud top pressure fields are taken from the International Satellite Cloud Climatology Project (ISCCP-D2) archive for the year 2000 (Rossow and Schiffer, 1999).

GLOMAP-mode is a two-moment aerosol microphysics scheme representing particles as an external mixture of seven size modes (four soluble and three insoluble) (Mann et al., 2010). We use the nitrate-extended version of GLOMAPmode (Benduhn et al., 2016) which, as well as tracking sizeresolved sulfate, BC, OC, sea-salt and dust components, also includes a dissolution solver to accurately characterise the size-resolved partitioning of ammonia and nitric acid into ammonium and nitrate components in each soluble mode. Aerosol components are assumed to be internally mixed within each mode. GLOMAP-mode includes representations of nucleation, particle growth via coagulation, condensation and cloud processing, wet and dry deposition, and in- and below-cloud scavenging (Mann et al., 2010).

TOMCAT includes a tropospheric gas-phase chemistry scheme (inclusive of $\mathrm{O}_{x}-\mathrm{NO}_{y}-\mathrm{HO}_{x}$ ), treating the degradation of $\mathrm{C}_{1}-\mathrm{C}_{3}$ non-methane hydrocarbons (NMHCs) and isoprene, together with a sulfur chemistry scheme (Spracklen et al., 2005; Breider et al., 2010; Mann et al., 2010). The tropospheric chemistry is coupled to aerosol as described in Breider et al. (2010).

The nitrate-extended version of the TOMCAT-GLOMAPmode coupled model used in this investigation employs a hybrid solver to simulate the dissolution of semi-volatile inorganic gases (such as $\mathrm{H}_{2} \mathrm{O}, \mathrm{HNO}_{3}, \mathrm{HCl}$ and $\mathrm{NH}_{3}$ ) into the aerosol-liquid-phase.

Emissions of DMS are calculated using monthly mean sea-water concentrations of DMS from (Kettle and Andreae, 2000), driven by ECMWF winds and sea-air exchange parameterisations from Nightingale et al. (2000). Emissions of $\mathrm{SO}_{2}$ are included from both continuous (Andres and Kasgnoc, 1998) and explosive volcanoes (Halmer et al., 2002), and wildfires for year 2000 (Van Der Werf et al., 2003; Dentener et al., 2006). Anthropogenic $\mathrm{SO}_{2}$ emissions (including industrial, power plant, road transport, off-road transport and shipping sectors) are representative of the year 2000 (Cofala et al., 2005). Emissions of monoterpenes and isoprene are from Guenther et al. (1995). $\mathrm{NH}_{3}$ emissions are from the EDGAR inventory (Bouwman et al., 1997). $\mathrm{NO}_{x}$ emissions are considered from anthropogenic (Lamarque et al., 2010), natural (Lamarque et al., 2005) and biomass burning (van der Werf et al., 2010) sources.

Annual mean emissions of BC and OC aerosol from fossil fuel and biofuel combustion are from Bond et al. (2004). Monthly wildfire emissions are taken from the GFED v1 (Global Fire Emissions Database) for the year 2000 (Van Der Werf et al., 2003). For primary aerosol emissions we use geometric mean diameters $\left(D_{\mathrm{g}}\right)$ with standard deviations as described by Mann et al. (2010).

Here, we ran simulations at a horizontal resolution of $2.8^{\circ} \times 2.8^{\circ}$ with 31 hybrid $\sigma-p$ levels extending from the surface to $10 \mathrm{hPa}$. All simulations were conducted for 16 months from September 1999 to December 2000 inclusive, with the first 4 months discarded as spin-up time.

\subsubsection{Model evaluation}

GLOMAP has been extensively evaluated against observations including comparisons of speciated aerosol mass (Mann et al., 2010; Spracklen et al., 2011b), aerosol number (Mann et al., 2010; Spracklen et al., 2010) and cloud condensation nuclei (CCN) concentrations (Spracklen et al., 2011a). TOMCAT simulated fields have been evaluated against observations, with $\mathrm{CO}$ and $\mathrm{O}_{3}$ evaluated against aircraft observations (Arnold et al., 2005), Mediterranean summertime 
ozone against satellite observations (Richards et al., 2013), along with $\mathrm{O}_{3}$ evaluated against satellite observations (Chipperfield et al., 2015). Benduhn et al. (2016) shows that simulated surface concentrations of $\mathrm{NO}_{3}$ and $\mathrm{NH}_{4}$ are in reasonable agreement with observations in Europe, the US and East Asia. Here we focus our evaluation on the aerosol vertical profile as well as nitrate aerosol which has not been evaluated previously.

Figure 1 presents simulated sulfate, nitrate, ammonium and organic aerosol mass concentrations in comparison to airborne observations compiled by Heald et al. (2011). The supplementary information presents the flight paths of each of the aircraft field campaigns used in the study compiled by Heald et al. (2011) (Fig. S1 in the Supplement), and details of each of the aircraft field campaigns used (Table S1 in the Supplement). Observations were predominantly made using an Aerodyne aerosol mass spectrometer (AMS). Simulated profiles are for year 2000, while observational aerosol profiles are from field campaigns conducted between 2001 and 2008.

Overall we find the model overestimates sulfates $[\mathrm{NMB}=+16.9 \%], \quad$ while underestimating nitrates $[\mathrm{NMB}=-60.7 \%]$, ammonium $[\mathrm{NMB}=-47.1 \%]$ and organic aerosols (OA) $[\mathrm{NMB}=-56.2 \%]$. Model skill varies depending on the conditions affecting each field campaign. To explore this, we use the broad stratification of the field campaigns into anthropogenic pollution, biomass burning and remote conditions as used by Heald et al. (2011) and shown in Fig. 1. The model underestimates aerosol concentrations in biomass burning regions [sulfate $\mathrm{NMB}=-14.9 \%$; nitrate $\mathrm{NMB}=-79.4 \%$; ammonium $\mathrm{NMB}=-68.7 \%$, and; $\mathrm{OA} \mathrm{NMB}=-74.5 \%$ ]. The model performs better in polluted [sulfate $\mathrm{NMB}=+31.6 \%$; nitrate $\mathrm{NMB}=-56.2 \%$; ammonium $\mathrm{NMB}=-28.6 \%$, and; $\mathrm{OA} \mathrm{NMB}=-40.9 \%$ ], and remote regions [sulfate $\mathrm{NMB}=+25.4 \% ; \quad$ nitrate $\mathrm{NMB}=-6.4 \% ; \quad$ ammonium $\mathrm{NMB}=-20.2 \%$, and; $\mathrm{OA} \mathrm{NMB}=-41.5 \%$ ].

The overestimation of sulfate aerosol is likely due to the decline in anthropogenic $\mathrm{SO}_{2}$ emissions in Europe and the US between 2000 and 2008 (Vestreng et al., 2007; Hand et al., 2012). An underestimation of OA has been reported previously (Heald et al., 2011; Spracklen et al., 2011b) and is likely due to an underestimate in SOA formation in the model. Whitburn et al. (2015) found biomass burning emissions of $\mathrm{NH}_{3}$ may be underestimated which would affect a number of our comparisons.

The model underestimation of organic and inorganic aerosol components in biomass burning influenced regions could partly be due to very concentrated plumes in these regions affecting campaign mean concentrations. There is a large uncertainty in biomass burning emissions and some evidence that they may be underestimated (Kaiser et al., 2012), which may contribute to the model bias. Biomass burning emissions also have large interannual variability (van der Werf et al., 2010; Wiedinmyer et al., 2011), meaning that using year-specific emissions might improve comparison against observations in these regions. Underestimation in Arctic inorganic aerosol, which will affect the ARCTAS comparisons, is a well-known problem in models, likely related to problems with model wet deposition and emissions (Shindell et al., 2008; Eckhardt et al., 2015). The model underestimate over West Africa (AMMA, DADEX and DODO campaigns) is likely due to a combination of errors in biomass burning emissions and poorly constrained emission sources from anthropogenic activity (Knippertz et al., 2015).

Figure 2 presents simulated ozone concentration profiles in comparison to ozonesonde observations compiled by Tilmes et al. (2012). Observations were compiled from three networks, comprising 41 stations with continuous sampling from 1995 to 2011: (i) The World Ozone and Ultraviolet Data Center (WOUDC) (http://www.woudc.org/); (ii) the Global Monitoring Division (GMD), and (iii) The Southern Hemisphere ADditional OZonesondes (SHADOZ) (Tilmes et al., 2012).

Regional model-observation comparison profiles presented in Fig. 2 demonstrate good agreement between the model and ozonesonde profiles, while demonstrating regional variations driven by variations in tropopause height, showing no evidence of systematic model bias in the upper troposphere. Notable differences are seen between simulated and observed ozone profiles over the Praha launch site in Western Europe, with the model greatly overestimating observed ozone.

Evaluation of ozone model bias is conducted for the troposphere, using a chemical tropopause definition of $150 \mathrm{ppbv}$ ozone, as previously used by Stevenson et al. (2013), Young et al. (2013) and Rap et al. (2015). We find the model overestimates global ozone concentrations $[\mathrm{NMB}=+7.0 \%]$ with overestimates in Western Europe $[+18.9 \%]$ and the Northern Hemisphere Polar West $[\mathrm{NMB}=+14.4 \%]$ regions and underestimates over the Atlantic/Africa $[\mathrm{NMB}=-11.0 \%$ ] and Southern Hemisphere Polar $[\mathrm{NMB}=-4.6 \%]$ regions.

Differences between model and observational profiles can in part be explained by the differences in years of simulation and observation, a poor representation of deep convection resulting in model underestimations in the tropics and overestimations downwind (Thompson et al., 1997), in tandem with reductions in anthropogenic $\mathrm{NO}_{x}$ emissions over this time period (Konovalov et al., 2008).

\subsection{Aviation emissions}

Aircraft emit $\mathrm{NO}_{x}$, carbon monoxide (CO), $\mathrm{SO}_{2}, \mathrm{BC}, \mathrm{OC}$ and hydrocarbons (HCs). The historical emissions data set for the CMIP5 (5th Coupled Model Intercomparison Project) model simulations used by the IPCC 5th Assessment Report only included $\mathrm{NO}_{x}$ and $\mathrm{BC}$ aviation emissions (Lamarque et al., 2009). Recently there have been efforts to add HCs, CO and $\mathrm{SO}_{2}$ emissions to aviation emission inventories (Eyers et 
(a) Sulfate comparison

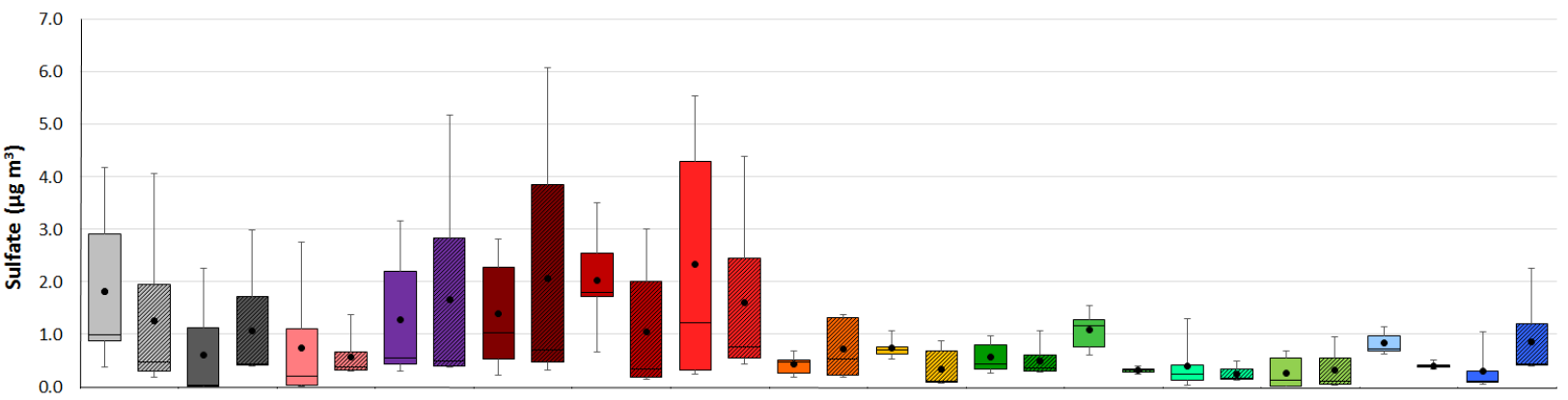

(b) Nitrate comparison

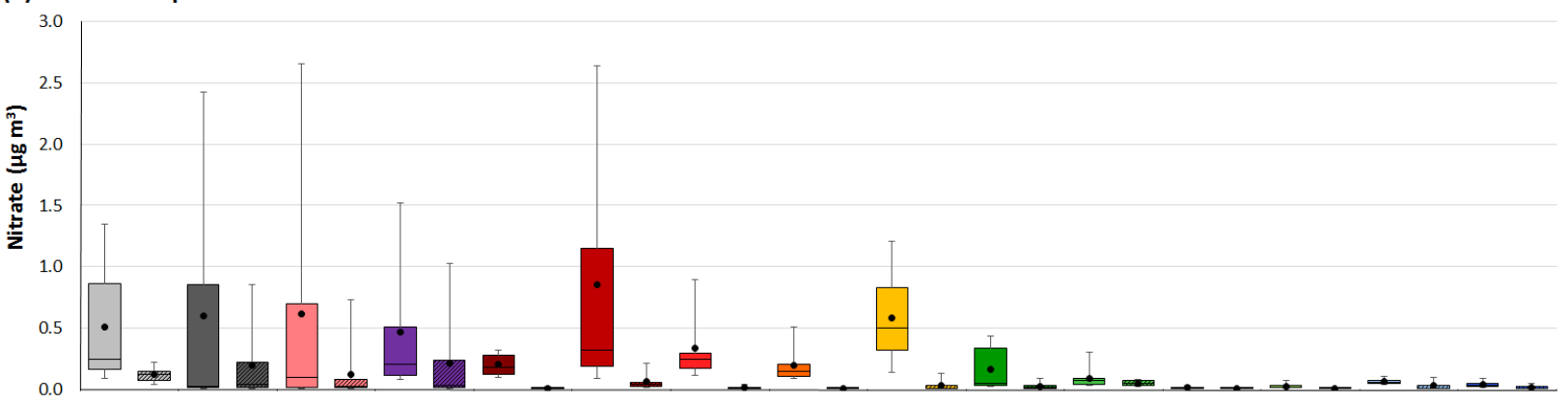

(c) Ammonium comparison

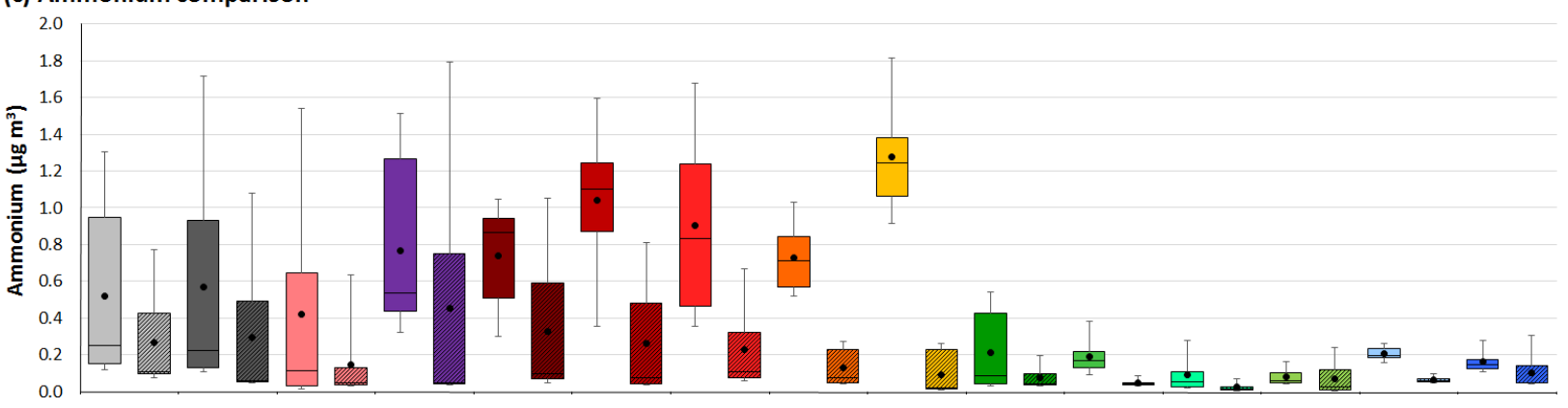

(d) Organic aerosol comparison

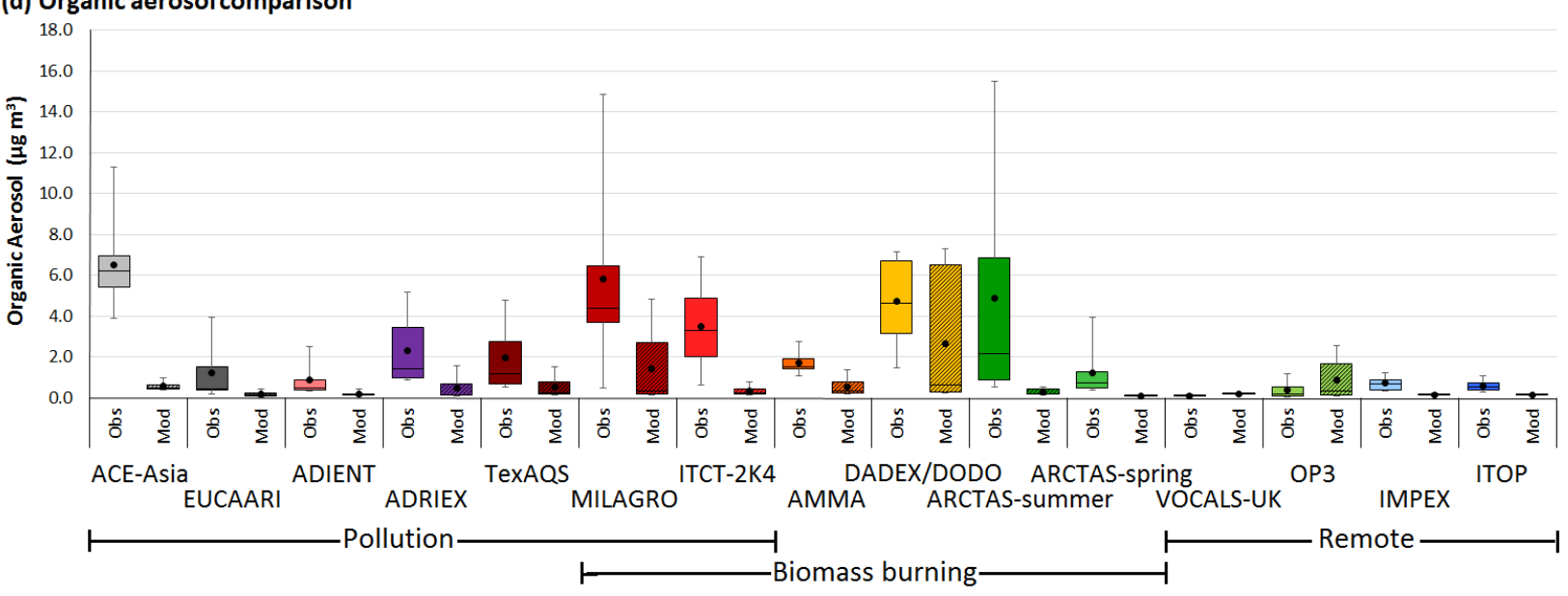

Figure 1. Comparison of observed (Obs) and simulated (Mod) (a) sulfate; (b) nitrate; (c) ammonium, and (d) organic aerosol mass concentrations. Observations are from airborne field campaigns compiled by Heald et al. (2011). Mean values are represented by black dots, median values as shown by horizontal lines, while boxes denote the 25 th and 75 th percentiles, and whiskers denote the 5 th and 95 th percentile values. 

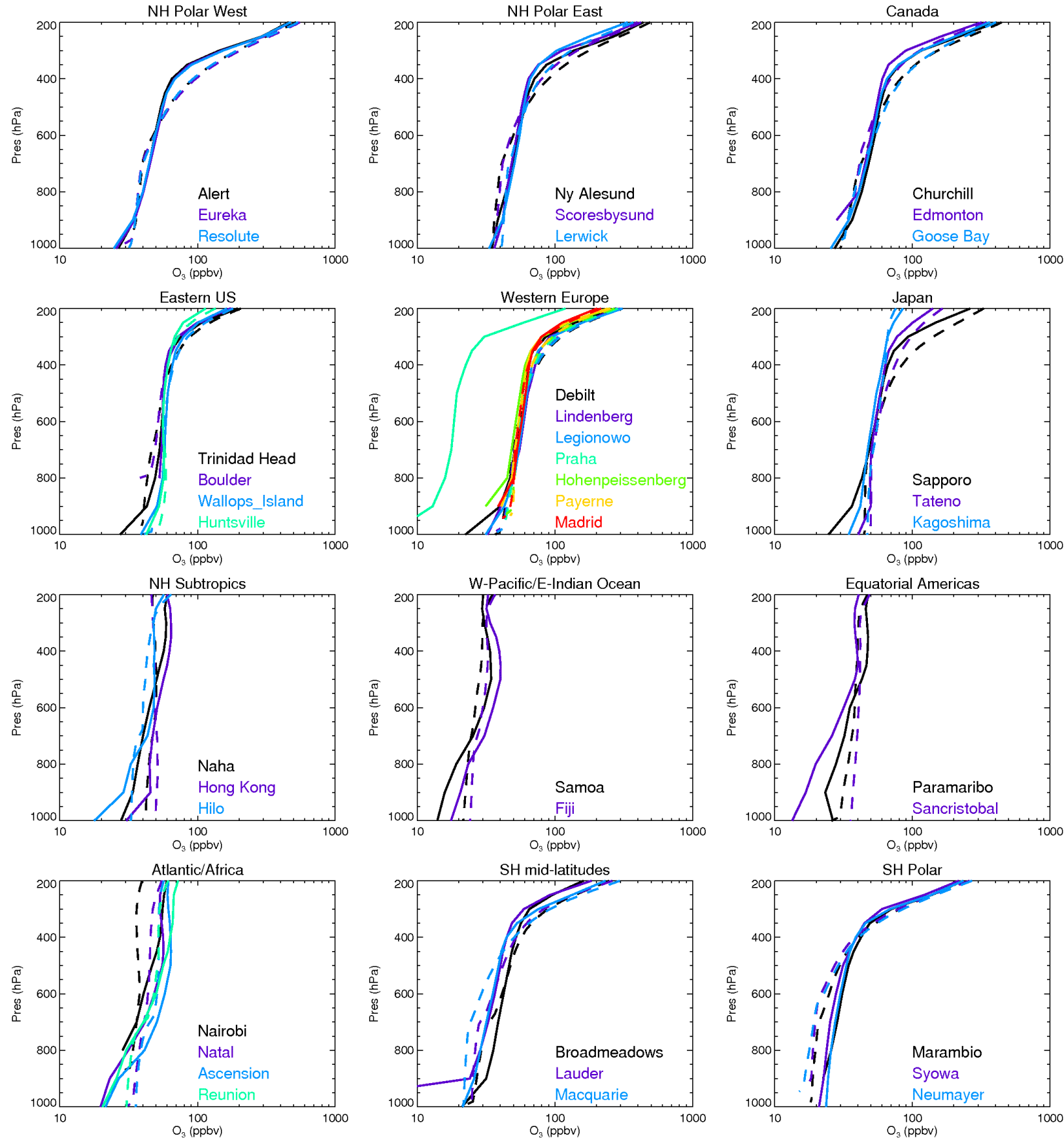

Figure 2. Comparison of observed (solid lines) and simulated (dashed lines) ozone profiles. Observations are taken from ozonesonde observations, and arranged by launch location regions according to Tilmes et al. (2012).

al., 2004; Quantify Integrated Project, 2005-2012; Wilkerson et al., 2010).

Here we develop a new 3-D civil aviation emissions data set for the year 2000, based on CMIP5 historical aviation emissions (Lamarque et al., 2009). The new data set includes emissions of $\mathrm{NO}_{x}, \mathrm{CO}, \mathrm{SO}_{2}, \mathrm{BC}, \mathrm{OC}$, and HCs. In contrast to existing data sets which provide a general emissions index for HCs (Eyers et al., 2004) we speciate HCs as formaldehyde $(\mathrm{HCHO})$, ethane $\left(\mathrm{C}_{2} \mathrm{H}_{6}\right)$, propane $\left(\mathrm{C}_{3} \mathrm{H}_{8}\right)$, methanol $\left(\mathrm{CH}_{3} \mathrm{OH}\right)$, acetaldehyde $\left(\mathrm{CH}_{3} \mathrm{CHO}\right)$, and acetone $\left(\left(\mathrm{CH}_{3}\right)_{2} \mathrm{CO}\right)$.

Table 1 describes our new emissions data set. $\mathrm{NO}_{x}$ and $\mathrm{BC}$ emissions are taken directly from Lamarque et al. (2009). We calculate fuel burn from $\mathrm{BC}$ emissions data and the $\mathrm{BC}$ emissions index (Eyers et al., 2004) as used by Lamarque et al. (2009). Following DuBois and Paynter (2006), we assume 
Table 1. Aviation emissions indices and total annual emissions for year 2000.

\begin{tabular}{lrrr}
\hline Species & $\begin{array}{r}\text { Emissions index } \\
\left(\mathrm{g} \mathrm{kg}^{-1} \text { of fuel }\right)\end{array}$ & $\begin{array}{r}\text { Global emissions for year } \\
2000(\text { Tg of species })\end{array}$ & $\begin{array}{r}\text { Range of annual global emissions from } \\
\text { previous studies (Tg of species) }\end{array}$ \\
\hline $\mathrm{NO}_{x}$ & $13.89^{\mathrm{a}}$ & 2.786 & $1.98-3.286^{\mathrm{a}, \mathrm{b}, \mathrm{j}, \mathrm{h}, \mathrm{i}, \mathrm{k}, \mathrm{l}}$ \\
$\mathrm{CO}$ & $3.61^{\mathrm{b}}$ & 0.724 & $0.507-0.679^{\mathrm{b}, \mathrm{h}, \mathrm{i}, \mathrm{j}}$ \\
$\mathrm{HCHO}$ & $1.24^{\mathrm{c}, \mathrm{d}}$ & 0.249 & $0.01205^{\mathrm{b}}$ \\
$\mathrm{C}_{2} \mathrm{H}_{6}$ & $0.0394^{\mathrm{e}}$ & 0.007899 & $0.00051^{\mathrm{b}}$ \\
$\mathrm{C}_{3} \mathrm{H}_{8}$ & $0.03^{\mathrm{e}}$ & 0.006014 & $0.00444^{\mathrm{b}}$ \\
$\mathrm{CH}_{3} \mathrm{OH}$ & $0.22^{\mathrm{d}}$ & 0.044 & $0.00177^{\mathrm{b}}$ \\
$\mathrm{CH}_{3} \mathrm{CHO}$ & $0.33^{\mathrm{d}}$ & 0.066 & $0.00418^{\mathrm{b}}$ \\
$\left(\mathrm{CH}_{3}\right)_{2} \mathrm{CO}$ & $0.18^{\mathrm{d}}$ & 0.036 & $0.00036^{\mathrm{b}}$ \\
$\mathrm{SO}_{2}$ & $1.1760^{\mathrm{b}}$ & 0.236 & $0.182-0.221^{\mathrm{a}, \mathrm{b}, \mathrm{h}, \mathrm{i}, \mathrm{j}}$ \\
$\mathrm{BC}_{\mathrm{OC}}$ & $0.0250^{\mathrm{a}}$ & 0.005012 & $0.0039-0.0068^{\mathrm{a}, \mathrm{b}, \mathrm{h}, \mathrm{i}, \mathrm{j}, \mathrm{k}}$ \\
$\mathrm{OC}^{\mathrm{b}}$ & $0.00625^{\mathrm{f}, \mathrm{g}}$ & 0.001253 & $0.003^{\mathrm{b}, \mathrm{i}}$ \\
\hline
\end{tabular}

a Eyers et al. (2004), ${ }^{\mathrm{b}}$ Wilkerson et al. (2010), ${ }^{\mathrm{c}}$ Spicer et al. (1994), ${ }^{\mathrm{d}}$ Knighton et al. (2007), ${ }^{\mathrm{e}}$ Anderson et al. (2006), ${ }^{\mathrm{f}}$ Bond et al. (2004), ${ }^{\mathrm{g}}$ Hopke (1985), ${ }^{\mathrm{h}}$ Olsen et al. (2013), ${ }^{\mathrm{i}}$ Unger (2011), ${ }^{\mathrm{j}}$ Lee et al. (2010), ${ }^{\mathrm{k}}$ Lamarque et al. (2010), ${ }^{1}$ Quantify Integrated Project (2005-2012).

that $\mathrm{BC}$ emissions scale linearly with fuel consumption. We estimate emissions for other species using our calculated aviation fuel burn in combination with published speciesspecific emissions indices (EI reported in $\mathrm{g} \mathrm{kg}^{-1}$ of fuel). Emission indices for $\mathrm{CO}$ and $\mathrm{SO}_{2}$ are from the FAA's aviation environmental design tool (AEDT) (Wilkerson et al., 2010). OC emissions are calculated using a BC: OC ratio of 4 (Bond et al., 2004); resulting in an EI within the range determined by Wayson et al. (2009). Speciated hydrocarbon emissions are calculated from experimental data following the methodology of Wilkerson et al. (2010) using experimental data from Knighton et al. (2007) and Anderson et al. (2006).

Our global aviation emissions typically lie within the range of previous studies (Table 1). Our $\mathrm{SO}_{2}$ emissions are greater than those used by Wilkerson et al. (2010) for 2006, despite the use of the same EI. This is due to the greater global fuel burn considered by the base inventory used to develop our emissions inventory (Eyers et al., 2004; Lamarque et al., 2010). Our estimated OC emissions are lower than the emissions estimated in the AEDT 2006 inventory, due to the lower EI applied here. The lower EI $\mathrm{ICC}_{\mathrm{C}}$ applied here (in comparison to Wilkerson et al., 2010) is a due to the phase of flight considered when deriving the AEDT emissions inventory; where they derive $\mathrm{EI}_{\mathrm{OC}}$ focusing on airport operations at ground-level condition acknowledging the risk of overestimating aviation OC emissions, while in comparison we consider aircraft operations after ground idle conditions which risks underestimating aviation OC emissions.

We calculate the geometric mean diameter $\left(D_{\mathrm{g}}\right)$ for internally mixed BC / OC particles as $50.5 \mathrm{~nm}$ from the mean particle mass derived using the particle number emissions index (Eyers et al., 2004) and a constant standard deviation set to $\sigma=1.59 \mathrm{~nm}$.

\subsection{Fuel sulfur content simulations}

To explore the impact of aviation FSC on climate and air quality we performed a series of 11 global model experiments (Table 2). In 7 of these model experiments FSC values were varied globally between zero and $6000 \mathrm{ppm}$. Three further simulations varied the vertical distribution of aviation emissions. The first simulation collapses all aviation emissions to ground level (GROUND), in order to compare an equivalent ground emission source and its effects. Two simulations (SWITCH1 and SWITCH2) use a low FSC (15 ppm) applied below the cruise phase of flight $(<8.54 \mathrm{~km}$ altitude) (Lee et al., 2009; Köhler et al., 2013) combined with a high FSC at altitudes above cruise level. The SWITCH1 scenario increases FSC in line with our HIGH scenario above $8.54 \mathrm{~km}$, while in the SWITCH2 scenario, emissions are scaled such that total global sulfur emissions are the same as the standard simulation (NORM), resulting in a FSC of $1420 \mathrm{ppm}$ above $8.54 \mathrm{~km}$. Results from all simulations are compared against a simulation with aviation emissions excluded (NOAVI).

\subsection{Radiative impacts}

We calculate the aerosol direct radiative effect (aDRE), aerosol cloud albedo effect (aCAE) and tropospheric $\mathrm{O}_{3}$ direct radiative effect (O3DRE) using the offline Edwards and Slingo (1996) radiative transfer model. The radiative transfer model considers six bands in the shortwave (SW) and nine bands in the longwave (LW), adopting a deltaEddington 2 stream scattering solver at all wavelengths. The top-of-the-atmosphere (TOA) aerosol aDRE and aCAE are calculated using the methodology described in Rap et al. (2013) and Spracklen et al. (2011a), with the method for O3DRE as in Richards et al. (2013). To determine the aCAE we calculated cloud droplet number concentrations 
Table 2. FSC and global $\mathrm{SO}_{2}$ emissions applied in each model experiment.

\begin{tabular}{llrr}
\hline $\begin{array}{l}\text { Scenario } \\
\text { name }\end{array}$ & Description & $\begin{array}{r}\text { FSC } \\
\text { (ppm) }\end{array}$ & $\begin{array}{r}\text { Total } \mathrm{SO}_{2} \\
\text { emitted (Tg) }\end{array}$ \\
\hline NOAVI & No aviation emissions & $\mathrm{n} / \mathrm{a}$ & 0.0 \\
NORM & Standard aviation emissions scenario & 600 & 0.236 \\
DESUL & Desulfurized case & 0 & 0.0 \\
ULSJ & Ultra low sulfur jet fuel & 15 & 0.006 \\
HALF & Half FSC of normal case & 300 & 0.118 \\
TWICE & Twice FSC of normal case & 1200 & 0.472 \\
HIGH & FSC at international specification limit & 3000 & 1.179 \\
OVER & Twice FSC specification limit & 6000 & 2.358 \\
GROUND & All emissions emitted at surface level (FSC as NORM) & 600 & 0.236 \\
SWITCH1 & ULSJ FSC to 8.54 km, HIGH FSC content above & $15 / 3000$ & 0.491 \\
SWITCH2 & ULSJ FSC to 8.54 km, FSC $=1420$ ppm above & $15 / 1420$ & 0.236 \\
\hline
\end{tabular}

(CDNCs) using the monthly mean aerosol size distribution simulated by GLOMAP combined with parameterisations from Nenes and Seinfeld (2003), updated by Fountoukis and Nenes (2005) and Barahona et al. (2010). CDNC were calculated with a prescribed updraft velocity of $0.15 \mathrm{~m} \mathrm{~s}^{-1}$ over ocean and $0.3 \mathrm{~m} \mathrm{~s}^{-1}$ over land. Changes to CDNC were then used to perturb the effective radii of cloud droplets in lowand mid-level clouds (up to $600 \mathrm{hPa}$ ). The aDRE, aCAE and O3DREs for each aviation emissions scenario are calculated as the difference in TOA net $(\mathrm{SW}+\mathrm{LW})$ radiative flux compared to the NOAVI simulation.

\subsection{Health effects}

We calculate excess premature mortality from cardiopulmonary diseases and increases in cases of lung cancer due to long-term exposure to aviation-induced $\mathrm{PM}_{2.5}$ (Ostro, 2004). Using this function allows us to compare our premature mortality estimates with those from previous studies (Barrett et al., 2012; Yim et al., 2015) using the same concentration function; in future work estimates are required with updated methodologies (Burnett et al., 2014). $\mathrm{PM}_{2.5}$ is used as a measure of likely health impacts because chronic exposure is associated with adverse human health impacts including morbidity and mortality (Dockery et al., 1993; Pope and Dockery, 2006).

We relate annual excess mortality to annual mean surface $\mathrm{PM}_{2.5}$ via a concentration response function (CRF) (Ostro, 2004). This response function considers concentrations of $\mathrm{PM}_{2.5}$ for a perturbed case $(X)$ (defined by aviation emissions scenarios from Table 2) in relation to a baseline case with no aviation emissions $\left(X_{0}\right)$ (NOAVI). To calculate excess mortality, the relative risk (RR) for both cardiopulmonary disease and lung cancer is calculated according to Ostro (2004) using a function of baseline $\left(X_{0}\right)$ and perturbed $(X) \mathrm{PM}_{2.5}$ concentrations, and the disease-specific, causespecific coefficient $(\beta)$ :
$\mathrm{RR}=\left[\frac{(X+1)}{\left(X_{0}+1\right)}\right]^{\beta}$

$\beta$ coefficients for cardiopulmonary disease mortality of $0.15515[95 \% \mathrm{CI}=0.05624-0.2541]$ and lung cancer of $0.232[95 \% \mathrm{CI}=0.086-0.379]$ are used (Pope et al., 2002; Ostro, 2004). The $95 \%$ confidence interval (CI) in $\beta$ allow low-, mid- and high-range mortality values to be calculated. The attribution factor (AF) from the exposure to air pollution is calculated using Eq. (2):

$\mathrm{AF}=(\mathrm{RR}-1) / \mathrm{RR}$.

Excess mortality $(E)$ for both cardiopulmonary disease and lung cancer is calculated using baseline mortality rates $(B)$, the fraction of the population over 30 years old $\left(P_{30}\right)$, along with the AF:

$E=\mathrm{AF} \times B \times P_{30}$.

Global population data are taken from the Gridded World Population (GWP; version3) project (Center for International Earth Science Information Network, 2012) with countryspecific data on the fraction of the population under 30 .

\section{Results}

\subsection{Surface $\mathbf{P M}_{2.5}$}

Figure 3 shows the simulated impact of aviation emissions with standard FSC (FSC $=600 \mathrm{ppm}$; NORM) on surface $\mathrm{PM}_{2.5}$ concentrations. Aviation increases annual mean $\mathrm{PM}_{2.5}$ concentrations by up to $\sim 80 \mathrm{ng} \mathrm{m}^{-3}$ (relative to the NOAVI simulation) over Central Europe and Eastern China (Fig. 3a). Aviation emissions result in largest fractional changes in annual mean $\mathrm{PM}_{2.5}$ concentrations (up to $0.8 \%$ ) over North America and Europe (Fig. 3b). 

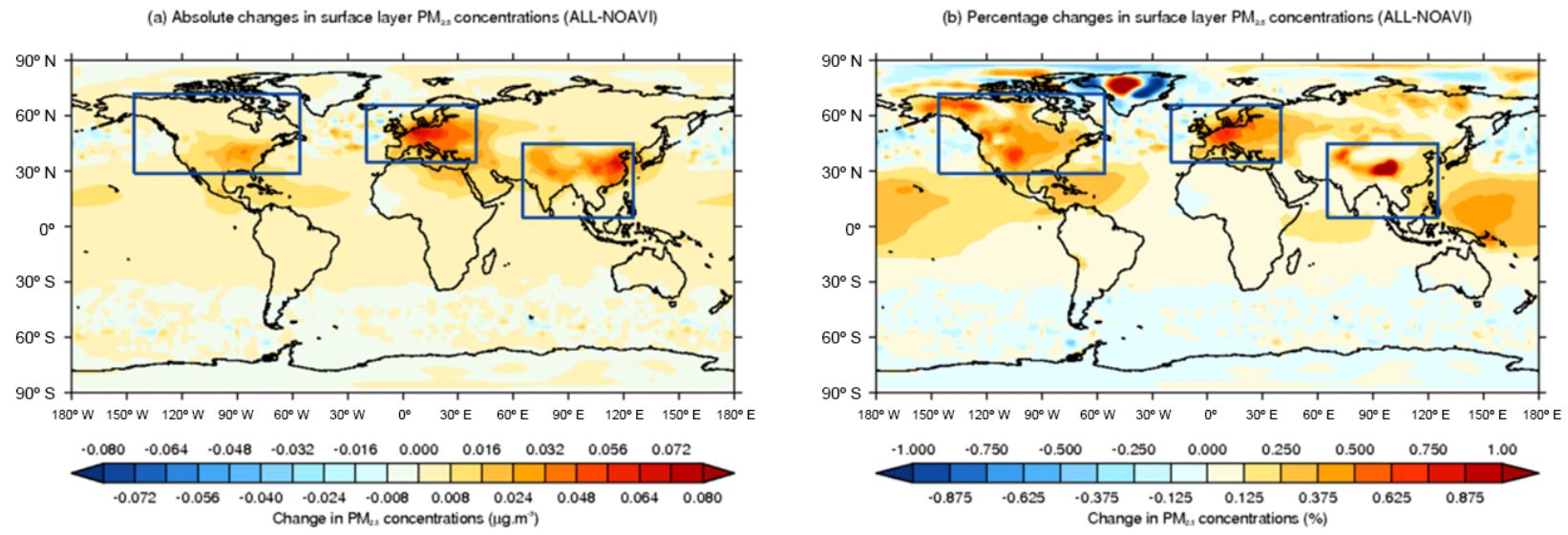

Figure 3. Impact of aviation emissions $(\mathrm{FSC}=600 \mathrm{ppm})$ on surface annual mean $\mathrm{PM}_{2.5}$ concentrations. (a) absolute (NORM-NOAVI) and (b) percentage changes. Boxes show the European $\left(20-40^{\circ} \mathrm{E}, 35-66^{\circ} \mathrm{N}\right)$ and North American $\left(146-56^{\circ} \mathrm{W}, 29-72^{\circ} \mathrm{N}\right)$ regions.

Table 3. Global aviation-induced aerosol mass burdens for different emission scenarios. Values in parentheses show percentage change relative to NORM case.

\begin{tabular}{|c|c|c|c|}
\hline Scenario & All components (Gg) & Sulfates (Gg) & Nitrates $(\mathrm{Gg})$ \\
\hline NORM & 16.9 & 12.9 & 5.7 \\
\hline ULSJ & $12.4(-26.8 \%)$ & $4.0(-69.1 \%)$ & $5.9(+4.5 \%)$ \\
\hline DESUL & $12.1(-28.4 \%)$ & $3.7(-71.6 \%)$ & $6.0(+5.1 \%)$ \\
\hline No $\mathrm{NO}_{x}$ and $\mathrm{SO}_{2}$ & $2.0(-88.3 \%)$ & $0.3(-97.5 \%)$ & $0.1(-97.9 \%)$ \\
\hline
\end{tabular}

Figure 4 shows the impact of aviation emissions on global and regional mean $\mathrm{PM}_{2.5}$ concentrations as a function of FSC. With standard FSC $(\mathrm{FSC}=600 \mathrm{ppm})$, aviation increases global mean surface $\mathrm{PM}_{2.5}$ concentrations by $3.9 \mathrm{ng} \mathrm{m}^{-3}$; with increases in $\mathrm{PM}_{2.5}$ dominated by sulfates [56.2\%], nitrates [26.0\%] and ammonium [16.0\%]. Aviation emissions increase European annual mean $\mathrm{PM}_{2.5}$ concentrations by $20.3 \mathrm{ng} \mathrm{m}^{-3}$ (Fig. 4b), substantially more than over North America (Fig. 4c) where an annual mean increase of $6.3 \mathrm{ng} \mathrm{m}^{-3}$ is simulated. Increased $\mathrm{PM}_{2.5}$ is dominated by nitrates, both over Europe [55.5\%] and over North America [ $44.4 \%]$. Sulfates contribute up to $44.6 \%$ of increases in $\mathrm{PM}_{2.5}$ over North America, and $30.0 \%$ over Europe.

The use of ULSJ fuel (FSC $=15 \mathrm{ppm}$ ) reduces global annual mean surface aviation-induced $\mathrm{PM}_{2.5}$ concentrations (in relation to the NORM case) by $35.7 \%$ [1.4 $\left.\mathrm{ng} \mathrm{m}^{-3}\right]$ (Fig. 4); predominantly due to changes in sulfate $\left[-1.4 \mathrm{ng} \mathrm{m}^{-3}\right.$; $-62.1 \%]$ and ammonium $\left[-0.2 \mathrm{ng} \mathrm{m}^{-3} ;-37.9 \%\right]$, which are marginally offset by very small increases in nitrates $\left[+3.2 \times 10^{-3} \mathrm{ng} \mathrm{m}^{-3} ;+0.3 \%\right]$. Aviation emissions also lead to small changes to other aerosol components of $+0.2 \mathrm{ng}$; which includes natural aerosols such as dust $\left[+0.3 \mathrm{ng} \mathrm{m}^{-3}\right.$; $+61.8 \%$ ], sodium [-19.5\%] and chloride from sea salt [-19.5\%] with the changes due to changes in aerosol lifetimes, along with changes in $\mathrm{BC}[-7.9 \%]$ and $\mathrm{OC}$ [-19.3\%].
In comparison to the global mean, switching to the use of ULSJ fuel in aviation larger absolute reductions in $\mathrm{PM}_{2.5}$ of $-4.2 \mathrm{ng} \mathrm{m}^{-3}$ are simulated over Europe $\left[\Delta\right.$ sulfate $=-3.4 \mathrm{ng} \mathrm{m}^{-3}$; $\Delta$ nitrate $=+0.1 \mathrm{ng} \mathrm{m}^{-3} ; \quad \Delta$ ammonium $=-0.8 \mathrm{ng} \mathrm{m}^{-3}$; and $\Delta$ others $\left.=-0.1 \mathrm{ng} \mathrm{m}^{-3}\right]$ and of $-3.4 \mathrm{ng} \mathrm{m}^{-3}$ over North America $\left[\Delta\right.$ sulfate $=-2.9 \mathrm{ng} \mathrm{m}^{-3}$; $\Delta$ nitrate $=+0.02 \mathrm{ng} \mathrm{m}^{-3} ; \quad \Delta$ ammonium $=-0.5 \mathrm{ng} \mathrm{m}^{-3}$; and $\Delta$ others $=-0.01 \mathrm{ng} \mathrm{m}^{-3}$ ] (Fig. $4 \mathrm{~b}, \mathrm{c}$ ). Over North America, swapping to ULSJ fuel reduces aviation-induced $\mathrm{PM}_{2.5}$ by $53.4 \%$, while a smaller reduction of $20.5 \%$ is simulated over Europe. The smaller fractional change in $\mathrm{PM}_{2.5}$ over Europe is caused by smaller reductions in aviation-induced sulfate [-55.9\%] and ammonium [-18.4\%] compared to over North America, which sees a reduction in ammonium of $41.6 \%$ and a reduction in sulfates of $103 \%$ indicating that over the US the ULSJ fuel scenario sees a reduction in sulfates in relation to a NOAVI scenario.

Complete desulfurization of jet fuel $(\mathrm{FSC}=0 \mathrm{ppm}$; DESUL) reduces global mean aviation-induced surface $\mathrm{PM}_{2.5}$ concentrations by $36.5 \%\left[-1.43 \mathrm{ng} \mathrm{m}^{-3}\right]$, with changes in sulfates $\left[-1.40 \mathrm{ng} \mathrm{m}^{-3} ;-63.5 \%\right]$ and ammonium $\left[-0.24 \mathrm{ng} \mathrm{m}^{-3} ;-38.8 \%\right]$ dominating. Under this scenario the reductions in surface sulfate $\mathrm{PM}_{2.5}$ from aviation are $57.3 \%$ over Europe and $105 \%$ over North America. ULSJ fuel therefore gives similar results to complete desul- 
(a) Global mean $\mathrm{PM}_{25}$ concentrations changes

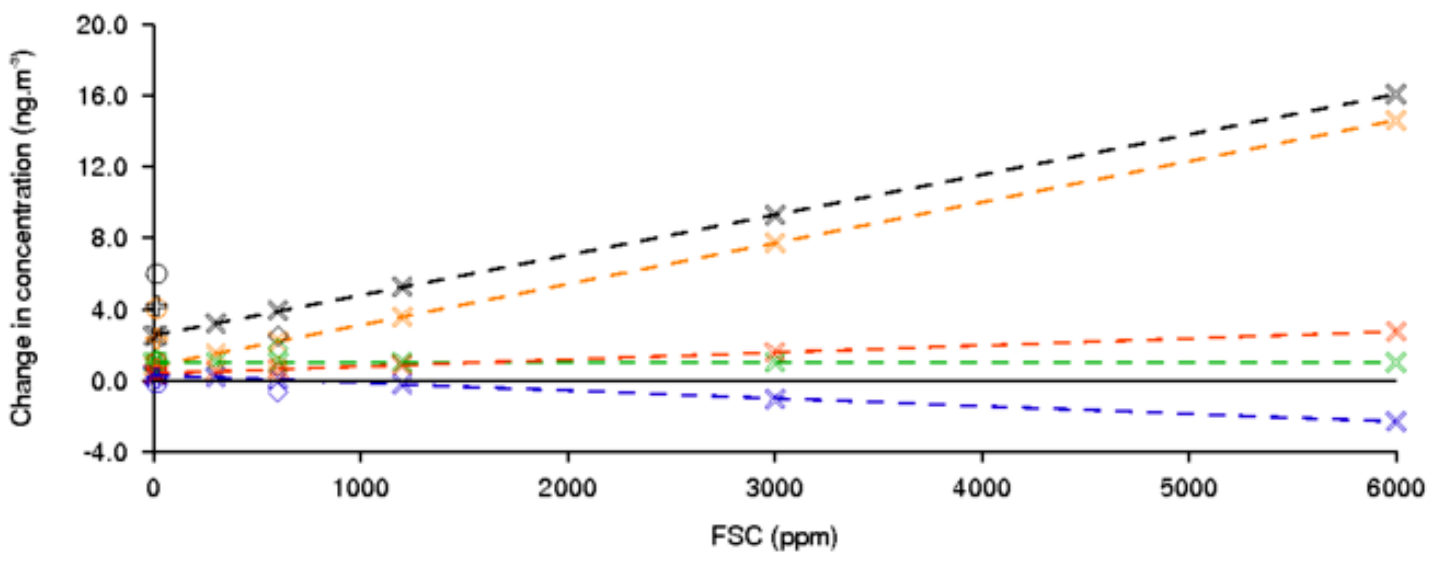

(b) European mean $\mathrm{PM}_{25}$ concentrations changes

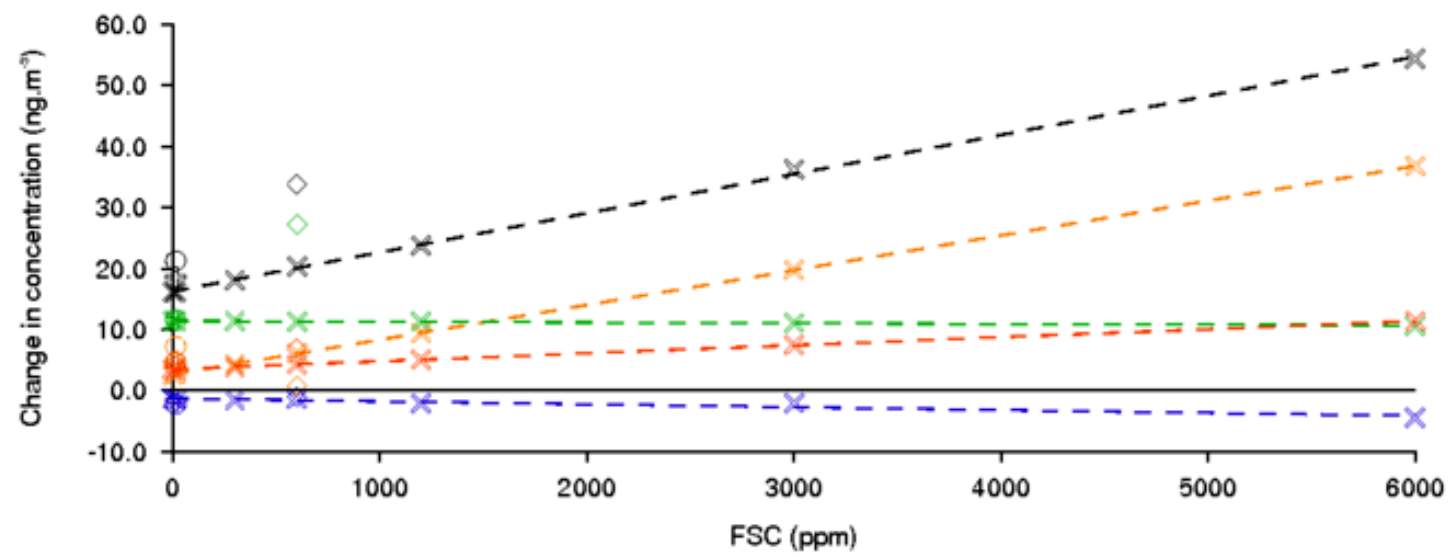

(c) North American mean $\mathrm{PM}_{2 s}$ concentrations changes

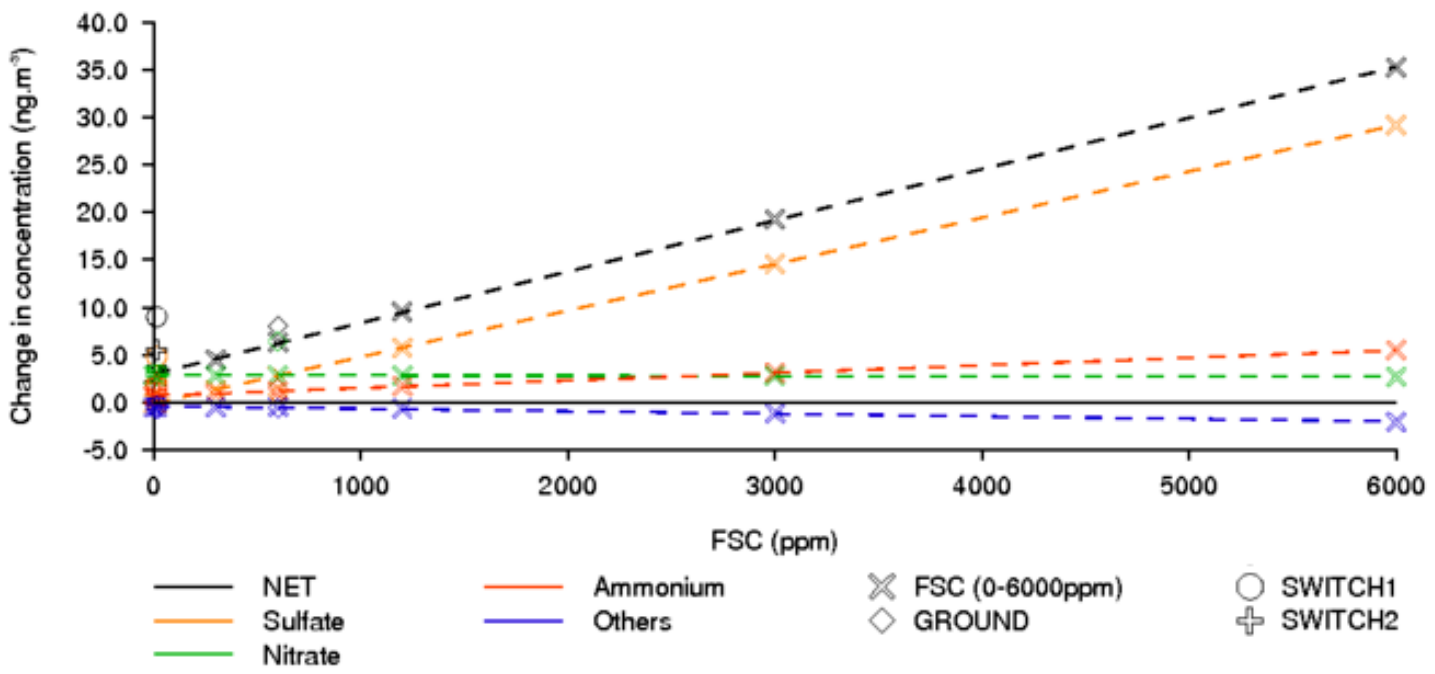

Figure 4. Impact of aviation FSC on (a) global, (b) European $\left(20-40^{\circ} \mathrm{E}, 35-66^{\circ} \mathrm{N}\right)$, (c) North American $\left(146-56^{\circ} \mathrm{W}, 29-72^{\circ} \mathrm{N}\right)$ surface annual mean $\mathrm{PM}_{2.5}$ mass concentrations: FSC variations $(\times)$, GROUND $(\diamond)$, SWITCH1 (-), and SWITCH2 (+) simulations. Solid lines demonstrate the linear relationship between FSC and $\mathrm{PM}_{2.5}$. 

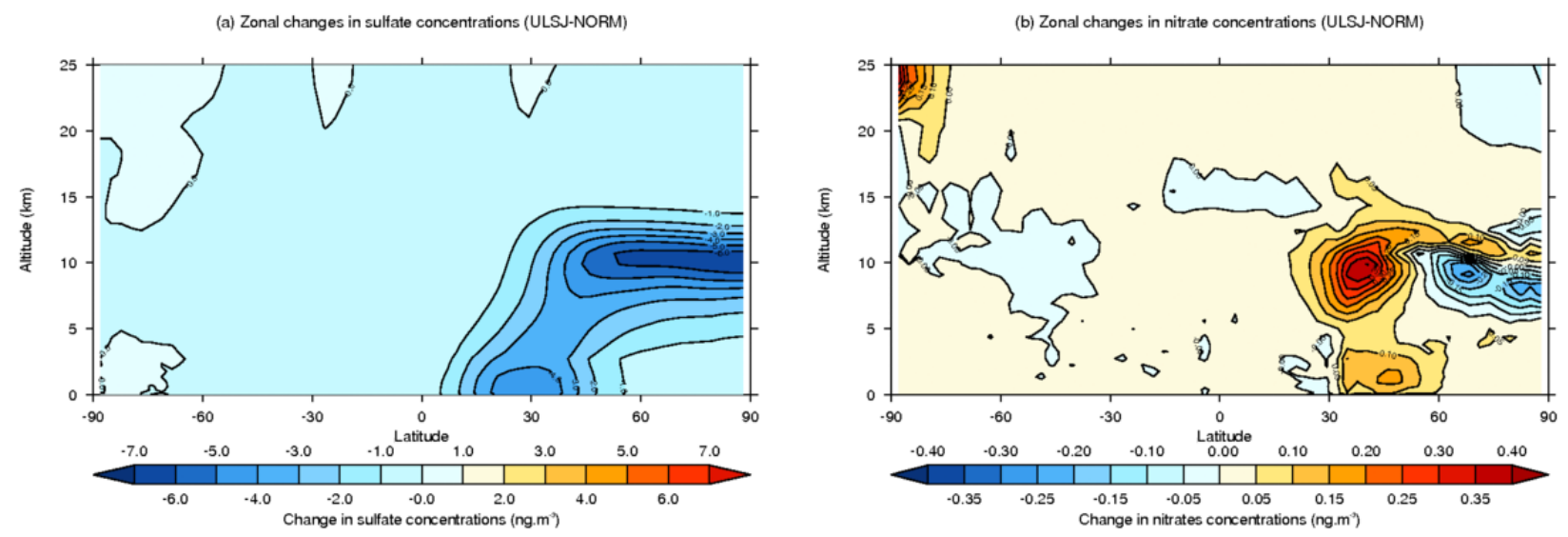

Figure 5. Simulated differences in zonal annual mean sulfate (a) and nitrate (b) concentrations from the use of ULSJ fuel relative to standard fuel (ULSJ-NORM).

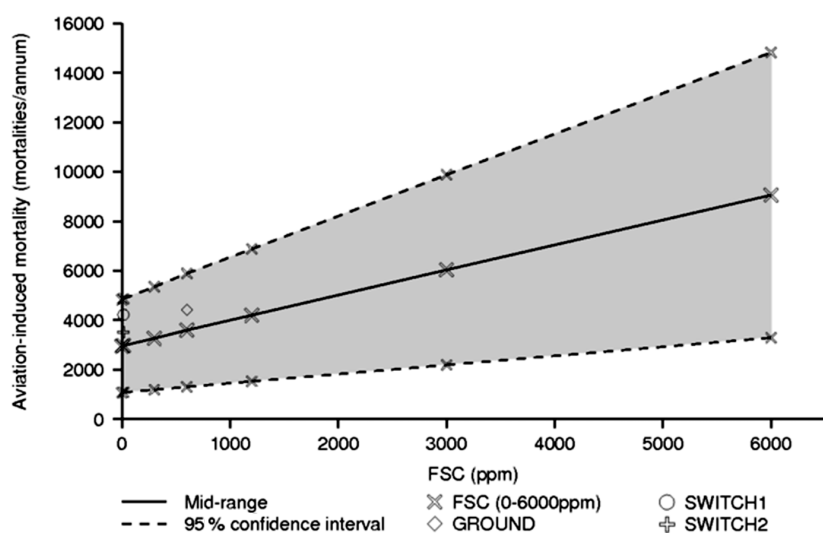

Figure 6. Estimated global aviation-induced mortality as a function of FSC, and changes in vertical aviation emission distributions for year 2000 (Shaded region denotes the $95 \%$ confidence through application of low- and high-range cause-specific coefficients).

furization, due to the very small sulfur emission from ULSJ fuel (Table 2).

In summary, increases in FSC result in increased surface $\mathrm{PM}_{2.5}$, due to increased sulfate outweighing the small reductions in nitrate. Simulated changes in sulfate, nitrate, ammonium and total $\mathrm{PM}_{2.5}$ are linear $\left(R^{2}>0.99, p\right.$ value $<0.001$ globally and for all individual regions) with respect to FSC (Fig. 4). Larger emission perturbations would likely lead to a non-linear response in atmospheric aerosol. The impact of variations in $\mathrm{FSC}$ on $\mathrm{PM}_{2.5}$ are regionally variable; over Europe changes in $\mathrm{PM}_{2.5}$ concentrations are observed to be more sensitive to changes in FSC than over North America, and the global domain.

Figure 5 shows the impact of changing to ULSJ fuel on zonal mean sulfate and nitrate concentrations relative to standard fuel (NORM). Table 3 reports the global aerosol burden from aviation under different emission scenarios. With standard FSC $(\mathrm{FSC}=600 \mathrm{ppm})$, the global aviation-induced aerosol burden is $16.9 \mathrm{Gg}$, dominated by sulfates $(76.3 \%)$ and nitrates $(33.4 \%)$. The use of ULSJ $(\mathrm{FSC}=15 \mathrm{ppm})$ reduces the global aerosol burden from aviation by $26.8 \%$. Complete desulfurization of aviation fuel reduces the global aerosol burden from aviation by $28.4 \%$, with the global sulfate burden from aviation reduced by $71.6 \%$ (Table 3 ). When aviation emissions contain no sulfur, aviation-induced sulfate is formed through aviation $\mathrm{NO}_{x}$-induced increases in $\mathrm{OH}$ concentrations, resulting in the oxidation of $\mathrm{SO}_{2}$ from nonaviation sources (Unger et al., 2006; Barrett et al., 2010).

In line with previous work, we find that a substantial fraction of aviation sulfate can be attributed to aviation $\mathrm{NO}_{x}$ emissions and not directly to aviation $\mathrm{SO}_{2}$ emissions. We estimate that $36 \%$ aviation-attributable sulfates formed at the surface are associated with aviation $\mathrm{NO}_{x}$ emissions, compared to $\sim 63 \%$ estimated by Barrett et al. (2010) using the GEOS-Chem model (both estimates for FSC $=600 \mathrm{ppm}$ ). Differences between model estimates can be attributed to differences in model chemistry and microphysics, and different aviation $\mathrm{NO}_{x}$ emissions. We find desulfurization increases the aviation nitrate burden by $5.1 \%$ (Table 3 ); although much of this increase occurs at altitudes well above the surface (Fig. 5) and so is not reflected in surface $\mathrm{PM}_{2.5}$ concentrations.

We explored the impacts of $\mathrm{NO}_{x}$ emission reductions in combination with fuel desulfurization. A scenario with desulfurized fuel and zero $\mathrm{NO}_{x}$ emissions reduces the global aviation-induced aerosol burden by $88.3 \%$ (Table 3), in comparison to a desulfurized only case (DESUL), where the aviation-induced aerosol burden is reduced by $28.4 \%$. Removal of aviation $\mathrm{NO}_{x}$ and $\mathrm{SO}_{2}$ emissions results in a $95.0 \%$ reduction in aviation-induced global mean surface level aviation-induced $\mathrm{PM}_{2.5}$. These results imply that only limited sulfate reductions can be achieved through reducing FSC alone, with further reductions in aviation-induced $\mathrm{PM}_{2.5}$ sulfates requiring additional controls on aviation $\mathrm{NO}_{x}$ emissions. 

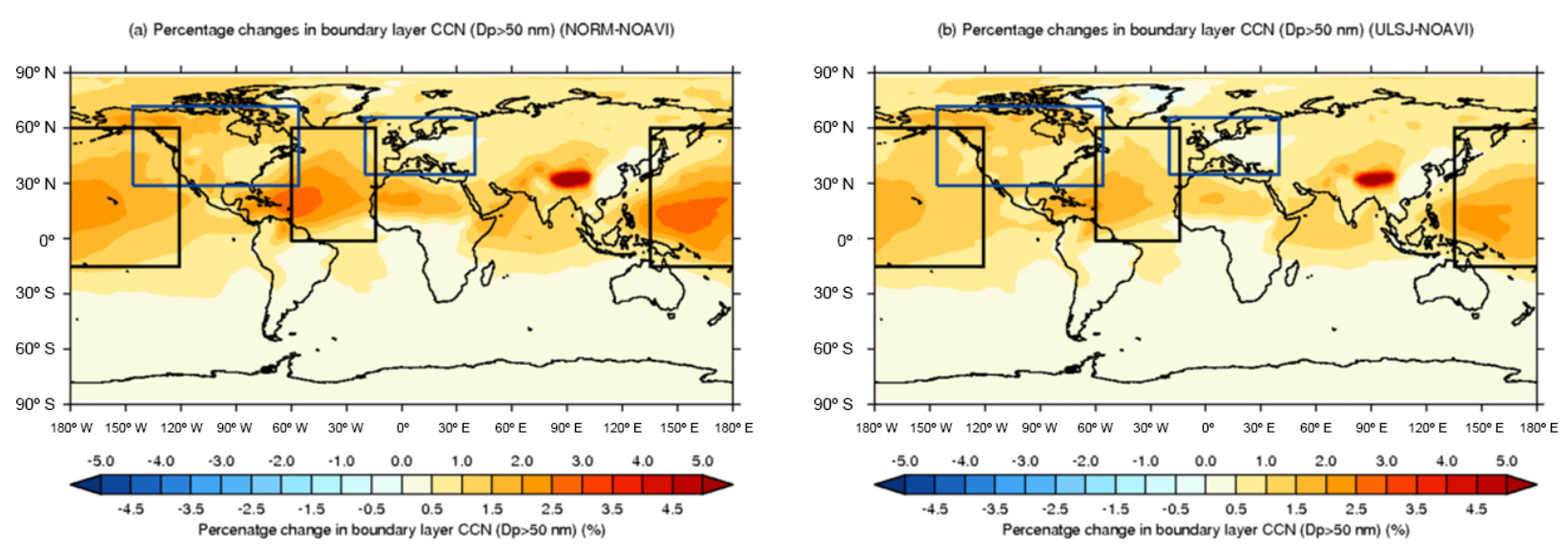

Figure 7. Impact of aviation emissions on low-cloud level ( $879 \mathrm{hPa}) \mathrm{CCN}\left(D_{\mathrm{p}}>50 \mathrm{~nm}\right)$ concentrations: (a) standard FSC (NORM-NOAVI) and (b) $\mathrm{FSC}=15 \mathrm{ppm}$ (ULSJ-NOAVI). Blue boxes define North American and European regions, and black boxes define Atlantic (60$\left.14^{\circ} \mathrm{W}, 1.4^{\circ} \mathrm{S}-60^{\circ} \mathrm{N}\right)$ and Pacific regions $\left(135^{\circ} \mathrm{E}-121^{\circ} \mathrm{W}, 15^{\circ} \mathrm{S}-60^{\circ} \mathrm{N}\right)$ referred to in the text.

\subsection{Premature mortality}

Figure 6 shows estimated annual premature mortalities (from cardiopulmonary disease and lung cancer) due to aviationinduced changes in $\mathrm{PM}_{2.5}$ as a function of FSC. We estimate that aviation emissions with standard FSC $(\mathrm{FSC}=600 \mathrm{ppm})$ cause 3600 [95\% CI: 1310-5890] premature mortalities each year, with 3210 [95\% CI: 1160-5250] mortalities a ${ }^{-1}$ due to increases in cases of cardiopulmonary disease and 390 [95\% CI: 150-640] mortalities a ${ }^{-1}$ due to increases in cases of lung cancer. Low-, mid- and high-range cause-specific coefficients $(\beta)$ are used to account for uncertainty in the health impacts caused by exposure to $\mathrm{PM}_{2.5}$ (Sect. 2.5) (Ostro, 2004). Our estimated global mortality due to aviation emissions is greatest in the Northern Hemisphere, which accounts for $98.7 \%$ of global mortalities. Europe and North America account for 42.3 and $8.4 \%$ of mortality due to aviation emissions respectively.

Our estimate of the premature mortality due to aviation lies within the range of previous estimates (310-13920 mortalities a $^{-1}$ ) (Barrett et al., 2010, 2012; Jacobson et al., 2013; Morita et al., 2014; Yim et al., 2004). Barrett et al. (2012) estimated $\sim 10000$ mortalities $\mathrm{a}^{-1}$ due to aviation, almost a factor of 3 higher than our central estimate. The greater aviation-induced mortality simulated by Barrett et al. (2012) can be attributed to greater aviation-induced surface $\mathrm{PM}_{2.5}$ concentrations simulated in their study, particulary over highly populated areas. Their study simulated maximum aviation-induced $\mathrm{PM}_{2.5}$ concentrations over Europe, eastern China and eastern North America greater than those in our simulations by factors of 5 for Europe and eastern China and 2.5 over eastern North America. Our aviation-induced sulfate concentrations compare well with Barrett et al. (2012), indicating that the resulting differences in aviation-induced surface $\mathrm{PM}_{2.5}$ concentrations are a result of other aerosol components. Additionally, differences in mortality arise due to the use of different cause-specific coefficients $(\beta)$ within the same CRF, as well as different population data sets. Morita et al. (2014) estimate that aviation is responsible for 405 [95\% CI: 182-648] mortalities $\mathrm{a}^{-1}$. This lower estimate is primarily due to the mortality functions used, with Morita et al. (2014) using the integrated exposure response (IER) function as described by Burnett et al. (2014). The IER function considers a $\mathrm{PM}_{2.5}$ concentration below which there is no perceived risk, reducing estimated impacts of aviation in regions of low $\mathrm{PM}_{2.5}$ concentrations.

We estimate that aviation emissions with ULSJ fuel result in 2970 [95\% CI: 1080-4870] premature mortalities globally per annum. Therefore, changing from standard FSC to ULSJ would result in 620 [95 \% CI: 230-1020] fewer premature mortalities globally per annum; a reduction in aviationinduced mortalities of $17.4 \%$. Regionally we find the implementation of an ULSJ fuel reduces annual mortality by 180 over Europe and by 110 over North America.

Barrett et al. (2012) estimated that swapping to ULSJ fuel could result in $\sim 2300$ [95\% CI: 890-4200] fewer premature mortalities globally per annum; a reduction of $23 \%$. In their work (using GEOS-Chem), the use of ULSJ reduces global mean $\mathrm{PM}_{2.5}$ concentrations (sulfates, nitrates and ammonium) by $0.89 \mathrm{ng} \mathrm{m}^{-3}$, less than the $1.61 \mathrm{ng} \mathrm{m}^{-3}$ reduction in $\mathrm{PM}_{2.5}$ simulated here). Despite the greater reductions in global mean surface layer $\mathrm{PM}_{2.5}$ concentrations simulated here, Barrett et al. (2012) simulate greater reductions in $\mathrm{PM}_{2.5}$ over populated regions, resulting in greater reductions of aviation-induced mortality under the ULSJ scenario. Additionally, the GRUMPv1 population data set that Barrett et al. (2012) use resolves population data on a finer scale compared to the resolution of GPWv3 population data set used here (Center for International Earth Science Information Network, 2012); differences which could contribute to differences in estimates of mortality. 
(a) Concentrations changes in $\mathrm{CCN}(\mathrm{Dp}>50 \mathrm{~nm})$

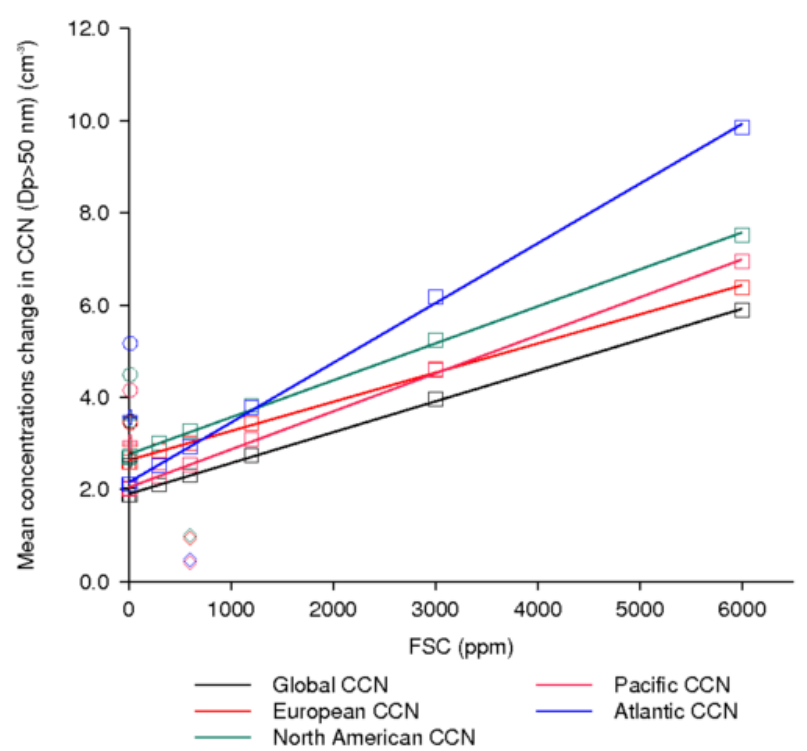

(b) Percentage changes in CCN (Dp>50 nm)

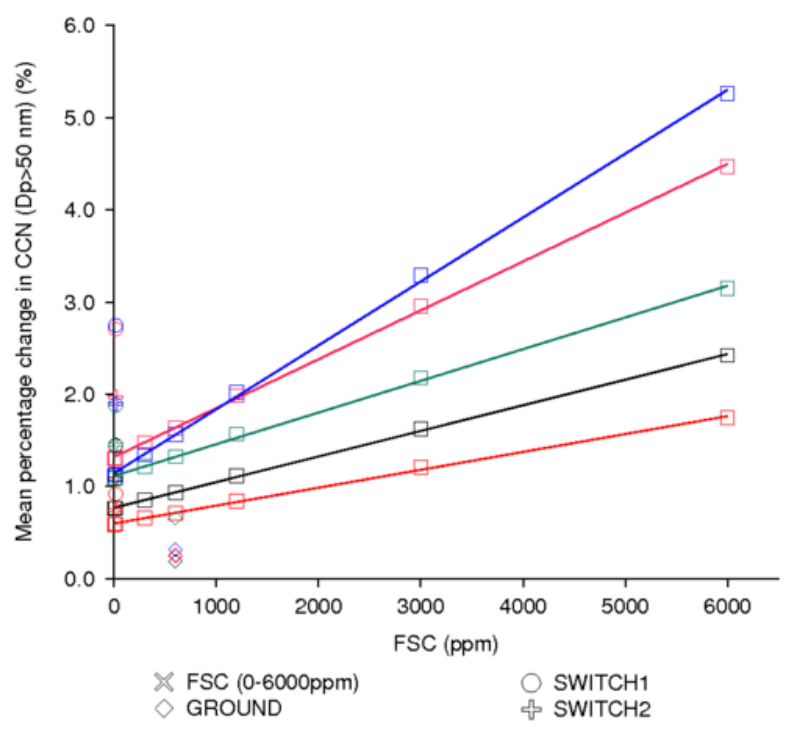

Figure 8. Global and regional variations in low-cloud level $(879 \mathrm{hPa}) \mathrm{CCN}\left(D_{\mathrm{p}}>50 \mathrm{~nm}\right)$ : (a) changes in mean concentrations and (b) percentage changes. See Fig. 5 for definitions of regions.

We also estimate how aviation-induced mortality would change if FSC was increased. We find that increasing FSC to $3000 \mathrm{ppm}$ (HIGH) would increase annual aviation-induced mortalities to 6030 , an increase of $67.8 \%$ in relation to standard aviation (NORM; FSC $=600 \mathrm{ppm}$ ).

\subsection{Sensitivity of cloud condensation nuclei to aviation FSC}

Aviation emissions with standard FSC (NORM; $\mathrm{FSC}=600 \mathrm{ppm}$ ) increase global annual mean cloud condensation nuclei $(\mathrm{CCN})$, here taken as the number of soluble particles with a dry diameter greater than $50 \mathrm{~nm}$, at low-cloud level $(879 \mathrm{hPa} ; 0.96 \mathrm{~km})$ by $0.9 \%\left(2.3 \mathrm{~cm}^{-3}\right)$ (Fig. 7a). Increases in $\mathrm{CCN}$ concentrations are greater in the Northern Hemisphere $\left[+3.9 \mathrm{~cm}^{-3} ;+1.4 \%\right]$ compared to the Southern Hemisphere $\left[+0.7 \mathrm{~cm}^{-3} ;+0.5 \%\right]$. Maximum increases in low-level CCN are simulated over the Pacific, central Atlantic and Arctic oceans.

The use of ULSJ $(\mathrm{FSC}=15 \mathrm{ppm})$ reduces global mean low-level CCN concentrations by $0.4 \mathrm{~cm}^{-3},[-18.2 \%]$ relative to the NORM case (Fig. 7). Northern Hemisphere CCN concentrations are reduced by $0.8 \mathrm{~cm}^{-3}$ [-19.4\%], while Southern Hemisphere concentrations are reduced by $0.1 \mathrm{~cm}^{-3}$ [-11.5\%] (Fig. 7).

Figure 8 shows the sensitivity of low level CCN concentrations to FSC. As with $\mathrm{PM}_{2.5}$, we find simulated changes in CCN are near linear with respect to FSC $\left(R^{2}>0.99\right.$ and $p$ value $<0.001$ globally and for all individual regions).

ULSJ fuel reduces global mean CCN by $-0.42 \mathrm{~cm}^{-3}$ with largest reductions over the Atlantic Ocean $\left[-0.81 \mathrm{~cm}^{-3}\right]$,
North America $\left[-0.55 \mathrm{~cm}^{-3}\right]$, and the Pacific Ocean $\left[-0.51 \mathrm{~cm}^{-3}\right]$, i.e. in relation to standard aviation (ULSJNORM). The complete desulfurization of aviation fuel results in reductions in $\mathrm{CCN}$ in relation to standard aviation (DESUL-NORM), which follow the same regional trends (Fig. 8a).

\subsection{Sensitivity of aerosol and ozone radiative effect to FSC}

shows the calculated global mean net RE due to non$\mathrm{CO}_{2}$ aviation emissions. For standard FSC (FSC $\left.=600 \mathrm{ppm}\right)$ emissions the global mean combined RE is $-13.3 \mathrm{~mW} \mathrm{~m}^{-2}$. This combined radiative effect $\left(\mathrm{RE}_{\mathrm{comb}}\right)$ results from a balance between a positive aDRE of $+1.4 \mathrm{~mW} \mathrm{~m}^{-2}$ and O3DRE $+8.9 \mathrm{~mW} \mathrm{~m}^{-2}$, and a negative aCAE of $-23.6 \mathrm{~mW} \mathrm{~m}^{-2}$ (Fig. 9).

Our estimated aviation aerosol DRE $\left[+1.4 \mathrm{~mW} \mathrm{~m}^{-2}\right]$ lies in the middle of the range given by previous work. The aviation aerosol DRE has been previously assessed as highly uncertain, ranging between -28 and $+20 \mathrm{~mW} \mathrm{~m}^{-2}$ (Righi et al., 2013). Our estimated aviation-induced aCAE $\left[-23.6 \mathrm{~mW} \mathrm{~m}^{-2}\right]$ lies within the range of uncertainty from previous literature: Righi et al. (2013) estimated $-15.4 \pm 10.6 \mathrm{~mW} \mathrm{~m}^{-2}$ and Gettelman and Chen (2013) estimated $-21 \pm 11 \mathrm{~mW} \mathrm{~m}^{-2}$.

Our O3DRE estimate $\left(+8.9 \mathrm{~mW} \mathrm{~m}^{-2}\right)$, normalised by global aviation $\mathrm{NO}_{x}$ emission to $+10.5 \mathrm{~mW} \mathrm{~m}^{-2} \mathrm{Tg}(\mathrm{N})^{-1}$, is at the lower end of current estimates [7.4$37.0 \mathrm{~mW} \mathrm{~m}^{-2} \mathrm{Tg}(\mathrm{N})^{-1}$ ] (Sausen et al., 2005; Köhler et al., 2008; Hoor et al., 2009; Lee et al., 2009; Holmes et 


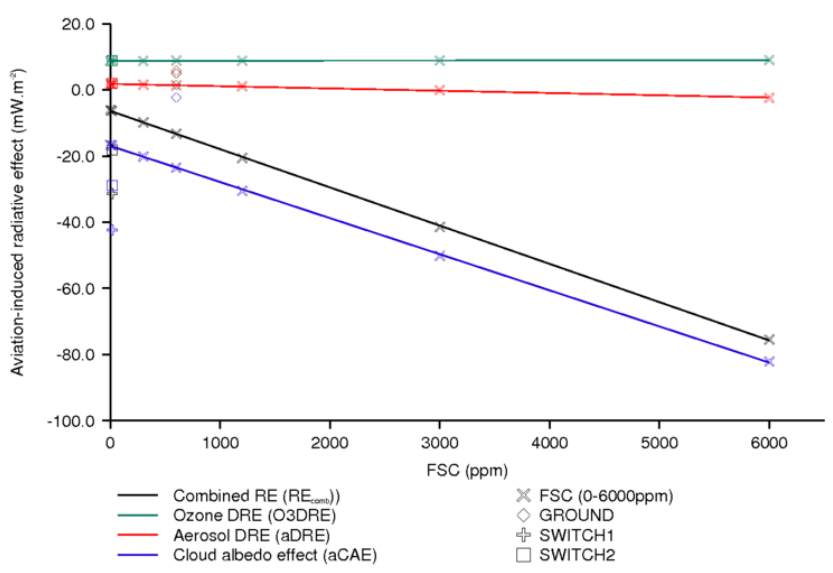

Figure 9. Aviation-induced radiative effects due to variations in fuel sulfur content (FSC), the ground release of aviation emissions (GROUND), and variations in the vertical distribution of aviation $\mathrm{SO}_{2}$ emissions (SWITCH1 and SWITCH2 simulations).

al., 2011; Myhre et al., 2011; Unger, 2011; Frömming et al., 2012; Skowron et al., 2013; Unger et al., 2013; Khodayari et al., 2014). This can be attributed to the lower net $\mathrm{O}_{3}$ chemical production efficiency (OPE) within our model (1.33). Unger (2011) estimated an O3DRE of $7.4 \mathrm{~mW} \mathrm{~m}^{-2} \mathrm{Tg}(\mathrm{N})^{-1}$ with a model OPE of $\sim 1$, while the ensemble of models considered by Myhre et al. (2011) have an OPE range of 1.5-2.4, resulting in an O3DRE range of $16.2-25.4 \mathrm{~mW} \mathrm{~m}^{-2} \mathrm{Tg}(\mathrm{N})^{-1}$.

We calculate that an aviation fleet utilising ULSJ fuel would result in a global annual mean $R_{\text {comb }}$ of $-6.3 \mathrm{~mW} \mathrm{~m}^{-2}\left[\mathrm{aDRE}=+1.8 \mathrm{~mW} \mathrm{~m}^{-2} ; \mathrm{aCAE}=-16.8 \mathrm{~mW}\right.$ $\mathrm{m}^{-2}$; and O3DRE $=+8.7 \mathrm{~mW} \mathrm{~m}^{-2}$ ]. Thus, swapping from standard aviation fuel to ULSJ fuel reduces the net cooling effect from aviation-induced aerosol and $\mathrm{O}_{3}$ by $7.0 \mathrm{~mW} \mathrm{~m}^{-2}$, in comparison to the reduction of $3.3 \mathrm{~mW} \mathrm{~m}^{-2}$ estimated by Barrett et al. (2012). In our model, this change is primarily due a reduction in cooling from the aCAE of $+6.7 \mathrm{~mW} \mathrm{~m}^{-2}$ combined with smaller contributions from an increased aDRE of $+0.4 \mathrm{~mW} \mathrm{~m}^{-2}$, and reduction in warming from the O3DRE of $-0.12 \mathrm{~mW} \mathrm{~m}^{-2}$ (Fig. 9).

When we assume fully desulfurized aviation jet fuel (DESUL; FSC $=0 \mathrm{ppm}$ ), the $\mathrm{RE}_{\text {comb }}$ induced by aviationinduced aerosol and $\mathrm{O}_{3}$ is very similar to that for ULSJ fuel and is estimated as $-6.1 \mathrm{~mW} \mathrm{~m}^{-2}\left[\mathrm{aDRE}=+1.8 \mathrm{~mW} \mathrm{~m}^{-2}\right.$; $\mathrm{aCAE}=-16.6 \mathrm{~mW} \mathrm{~m}^{-2}$; and O3DRE $\left.=+8.7 \mathrm{~mW} \mathrm{~m}^{-2}\right]$.

Increases in FSC result in reductions in the aerosol DRE (aDRE), changing from a positive aerosol DRE for low FSC scenarios, to a negative aerosol DRE for high FSC (FSC $>1200 \mathrm{ppm}$ ). As FSC is increased, we find the aCAE exhibits a larger cooling effect, i.e. becoming more negative with increases in FSC, increasing by a factor $\sim 5$ as FSC is increased from 0 to $6000 \mathrm{ppm}$. The $\mathrm{RE}_{\text {comb }}$ is dominated by these changes to the aCAE. Increases in FSC from 0 to $6000 \mathrm{ppm}$ result in a greater negative (cooling) aviation-

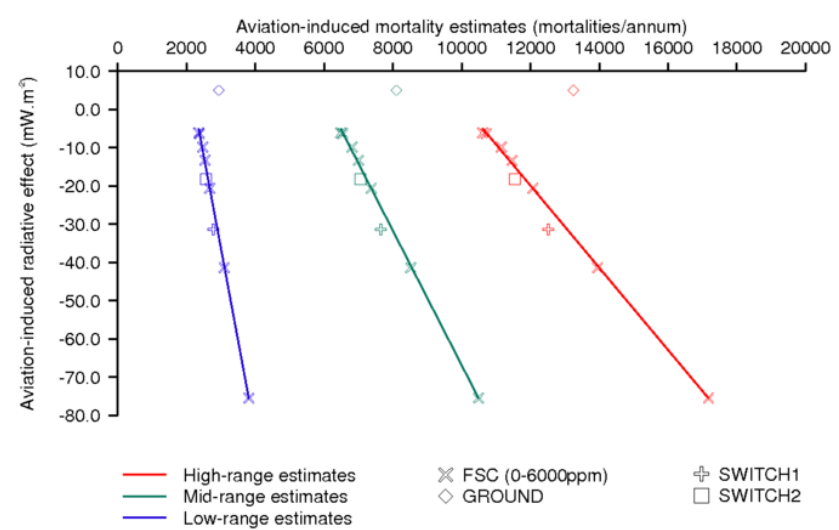

Figure 10. Relationship between net radiative effect (sum of ozone direct (O3DRE), aerosol direct radiative (aDRE) and aerosol cloud albedo (aCAE) effects) and annual mortality rates: for low- midand high-range mortality sensitivities.

induced $\mathrm{RE}_{\mathrm{comb}}$; increasing in magnitude by a factor of $\sim 5\left(-16.6 \mathrm{~mW} \mathrm{~m}^{-2}\right.$ for FSC $=0 \mathrm{ppm}$ to $-82.1 \mathrm{~mW} \mathrm{~m}^{-2}$ for $\mathrm{FSC}=6000 \mathrm{ppm})($ Fig. 9). Therefore, we find that increases in FSC provide a cooling effect due to the dominating effect from aviation-induced aCAE.

\subsection{Relationship between aviation-induced radiative effects and mortality due to aviation non- $\mathrm{CO}_{2}$ emissions}

Figure 10 shows the net RE and premature mortality for different aviation emission scenarios. Increases in FSC lead to approximately linear increases in both estimated mortality and the negative net RE. We quantify the impact of FSC on mortality and REs in terms of $\mathrm{d}$ (mortalities)/d(FSC) [mortalities $\mathrm{ppm}^{-1}$ ] and $\mathrm{d}(\mathrm{RE}) / \mathrm{d}(\mathrm{FSC})\left[\mathrm{mW} \mathrm{m}^{-2} \mathrm{ppm}^{-1}\right]$. We calculate the sensitivity of global premature mortality to be 1.0 mortalities $\mathrm{ppm}^{-1}$ [95\% CI $=0.4$ to 1.6 mortalities $\mathrm{ppm}^{-1}$, where the range is due to uncertainty in $\beta$ ]. The global mean $\mathrm{RE}_{\text {comb }}$ has a sensitivity of $-1.2 \times 10^{-2} \mathrm{~mW} \mathrm{~m}^{-2} \mathrm{ppm}^{-1}$, dominated by large changes to the aCAE $\left[-1.1 \times 10^{-2} \mathrm{~mW} \mathrm{~m}^{-2} \mathrm{ppm}^{-1}\right]$, and much smaller changes in the aDRE $\left[-6.9 \times 10^{-4} \mathrm{~mW} \mathrm{~m}^{-2} \mathrm{ppm}^{-1}\right]$ and $\mathrm{O}_{3} \mathrm{RE}$ $\left[+4.4 \times 10^{-5} \mathrm{~mW} \mathrm{~m}^{-2} \mathrm{ppm}^{-1}\right]$.

The different slopes in the relationship between estimated RE and mortality (Fig. 10) are driven by the range of coefficients used in the CRF. This highlights the considerable uncertainty in the health impacts caused by exposure to $\mathrm{PM}_{2.5}$. We note that uncertainty in the RE due to aerosol and ozone exists, but is not included in Fig. 9.

To assess how the vertical distributions of aviation $\mathrm{SO}_{2}$ emissions influence human health and climate effects, we performed three additional simulations where we altered the vertical distribution of aviation $\mathrm{SO}_{2}$ emissions (GROUND, SWITCH1 and SWITCH2 simulations). In these simulations 
the relationships between mortality and net RE deviate from the linear relationship seen when varying FSC between 0 and 6000 ppm (Fig. 10).

In relation to the standard aviation emissions simulation $(\mathrm{FSC}=600 \mathrm{ppm}$; NORM), when we release all aviation emissions at the surface (GROUND; FSC $=600 \mathrm{ppm}$ ) aviation-induced surface $\mathrm{PM}_{2.5}$ concentrations increase by $+13.5 \mathrm{ng} \mathrm{m}^{-3}[+65.7 \%]$ over Europe and by $+1.7 \mathrm{ng} \mathrm{m}^{-3}$ $[+27.1 \%]$ over North America, but decrease by $-1.4 \mathrm{ng} \mathrm{m}^{-3}$ [-36.7\%] globally (Fig. 4). Greater surface layer $\mathrm{PM}_{2.5}$ perturbations (GROUND-NORM) over populated regions increase aviation-induced annual mortality by $+22.9 \%$ [+830 mortalities a $\left.{ }^{-1}\right]$ (Fig. 6).

Releasing aviation emissions at the surface (GROUND case) increases global mean cloud level $\mathrm{CCN}$ by only $0.4 \mathrm{~cm}^{-3}$ relative to NOAVI; providing a reduction in CCN of $82.1 \%\left[-1.89 \mathrm{~cm}^{-3}\right]$ relative to the NORM case (i.e. GROUND-NORM). That is, injecting aviation emissions into the free troposphere in the standard scenario is over 5 times more efficient at increasing CCN concentrations compared to when the same emissions are released at the surface [GROUND $\mathrm{CCN}=0.4 \mathrm{~cm}^{-3}$; NORM $\left.\mathrm{CCN}=2.3 \mathrm{~cm}^{-3}\right]$; both in relation to the NOAVI scenario. Similar behaviour has been demonstrated previously for volcanic $\mathrm{SO}_{2}$ emissions by Schmidt et al. (2012), where volcanic $\mathrm{SO}_{2}$ emissions injected into the free troposphere (FT) were more than twice as effective at producing new CCN compared to boundary layer emissions of DMS. Injection of aviation $\mathrm{SO}_{2}$ emissions at the surface will increase both deposition rates and aqueous phase oxidation of $\mathrm{SO}_{2}$; the latter resulting in the growth of existing $\mathrm{CCN}$, but not the formation of new CCN. In contrast, when $\mathrm{SO}_{2}$ is emitted into the FT the dominant oxidation mechanism is to $\mathrm{H}_{2} \mathrm{SO}_{4}$, leading to the formation of new $\mathrm{CCN}$ through particle formation and the condensational growth of particles to larger sizes. Subsequent entrainment of these new particles into the lower atmosphere results in enhanced CCN concentrations in low-level clouds. Reduced CCN formation when aviation emissions are injected at the surface has implications for the aCAE. When aviation emissions are released at the surface we calculate an aCAE of $-2.3 \mathrm{~mW} \mathrm{~m}^{-2}$; a factor of 10 smaller than the standard aviation scenario. This demonstrates that low-level CCN concentrations and the aCAE are particularly sensitive to aviation emissions, because of the efficient formation of $\mathrm{CCN}$ when $\mathrm{SO}_{2}$ emissions are injected into the FT. Injecting aviation emissions at the surface also results in an increase in the aDRE of $+5.9 \mathrm{~mW} \mathrm{~m}^{-2}$, resulting in an $\mathrm{RE}_{\mathrm{comb}}$ of $+5.0 \mathrm{~mW} \mathrm{~m}^{-2}$ (Fig. 9).

Surface $\mathrm{O}_{3}$ concentrations are also less sensitive to aviation when emissions are located at the surface. Global mean aviation-induced surface $\mathrm{O}_{3}$ concentrations are reduced from $0.15 \mathrm{ppbv}$ (NORM) to $0.03 \mathrm{ppbv}$ when all emissions are in the surface layer. Releasing aviation emissions at the surface also reduces the global $\mathrm{O}_{3}$ burden by $3.1 \mathrm{Tg}$. These perturbations in $\mathrm{O}_{3}$ concentrations result in a reduction in the $\mathrm{O}_{3}$ ra- diative effect from $+8.9 \mathrm{~mW} \mathrm{~m}^{-2}(\mathrm{NORM} ; \mathrm{FSC}=600 \mathrm{ppm})$ to $+1.5 \mathrm{~mW} \mathrm{~m}^{-2}$ (GROUND; FSC $=600$ ppm) (Fig. 9). This is a reflection of increases in the OPE of $\mathrm{NO}_{x}$ with increases in altitude due to lower background $\mathrm{NO}_{x}$ and $\mathrm{NMHC}$ (nonmethane hydrocarbon) concentrations (Köhler et al., 2008; Stevenson and Derwent, 2009; Snijders and Melkers, 2011; Skowron et al., 2013).

We investigated altering FSC between the take-off/landing and the cruise phases of flight using two scenarios (SWITCH1 and SWITCH2) (Table 2). Our SWITCH1 scenario increases global mean aviation-induced surface layer $\mathrm{PM}_{2.5}$ concentrations by $+2.1 \mathrm{ng} \mathrm{m}^{-3}$ [52.2\%], European mean concentrations by $+0.9 \mathrm{ng} \mathrm{m}^{-3}[+4.5 \%]$, and North American concentrations by $+2.7 \mathrm{ng} \mathrm{m}^{-3}[+42.2 \%]$ relative to NORM (Fig. 4). These changes increase aviation-induced mortality by $+17.4 \%\left[+630\right.$ mortalities $\left.a^{-1}\right]$ (Fig. 6). This scenario results in greater global mean increases in $\mathrm{CCN}$ (relative to NORM) of $+1.2 \mathrm{~cm}^{-3}[+51.2 \%]$, a larger cooling aCAE $\left[-42.4 \mathrm{~mW} \mathrm{~m}^{-2}\right]$, larger warming aDRE $\left[2.07 \mathrm{~mW} \mathrm{~m}^{-2}\right]$, resulting in additional $-18.1 \mathrm{~mW} \mathrm{~m}^{-2}$ [136\%] of aviation-induced cooling [SWITCH1 RE $\mathrm{Romb}_{\text {of }}$ $-31.4 \mathrm{~mW} \mathrm{~m}^{-2}$ ].

The SWITCH2 scenario was designed to have the same global total sulfur emission as the normal aviation simulation. SWITCH2 increased global mean surface aviationinduced $\mathrm{PM}_{2.5}$ concentrations by $+0.3 \mathrm{ng} \mathrm{m}^{-3}$ [+6.6\%], but reduces mean surface $\mathrm{PM}_{2.5}$ concentrations over Europe $\left[-1.8 \mathrm{ng} \mathrm{m}^{-3} ;-8.7 \%\right]$ and North America $\left[-0.8 \mathrm{ng} \mathrm{m}^{-3}\right.$; $-12.8 \%$ ] compared to NORM. Under this scenario global aviation-induced mortality is decreased by $2.4 \%$ [ -90 mortalities $\left.\mathrm{a}^{-1}\right]$ compared to the standard aviation simulation (Fig. 6). The SWITCH2 scenario results in a $\mathrm{RE}_{\text {comb }}$ of $-18.2 \mathrm{~mW} \mathrm{~m}^{-2}$, providing an additional $-4.9 \mathrm{~mW} \mathrm{~m}^{-2}$ [36.6\%] cooling in relation to standard aviation emissions (NORM; FSC $=600 \mathrm{ppm}$ ).

\section{Discussion and conclusions}

We have used a coupled chemistry-aerosol microphysics model to estimate the impact of aviation emissions on aerosol and $\mathrm{O}_{3}$ concentrations, premature mortality and radiative effect on climate.

We calculated the top-of-atmosphere (TOA) tropospheric $\mathrm{O}_{3}$ radiative effect (O3DRE), aerosol direct $\mathrm{RE}$ (aDRE) and aerosol cloud albedo effect (aCAE). We find that these non$\mathrm{CO}_{2}$ REs result in a net cooling effect on climate as has been found previously (Sausen et al., 2005; Lee et al., 2009; Gettelman and Chen, 2013; Righi et al., 2013; Unger et al., 2013). For year 2000 aviation emissions with a standard fuel sulfur content $(\mathrm{FSC}=600 \mathrm{ppm})$, we calculate a global annual mean net TOA RE of $-13.3 \mathrm{~mW} \mathrm{~m}^{-2}$, due to a combination of O3DRE $\left[+8.9 \mathrm{~mW} \mathrm{~m}^{-2}\right]$, aDRE $\left[+1.4 \mathrm{~mW} \mathrm{~m}^{-2}\right]$ and aCAE $\left[-23.6 \mathrm{~mW} \mathrm{~m}^{-2}\right]$. 
Our O3DRE $\left[+8.9 \mathrm{~mW} \mathrm{~m}^{-2}\right]$ when normalised to represent the impact of the emissions of $1 \mathrm{Tg}(\mathrm{N})$ $\left[+10.45 \mathrm{~mW} \mathrm{~m}^{-2} \mathrm{Tg}(\mathrm{N})^{-1}\right]$ is at the lower end of the range provided by previous studies [7.39$36.95 \mathrm{~mW} \mathrm{~m}^{-2} \mathrm{Tg}(\mathrm{N})^{-1}$ ] (Sausen et al., 2005; Hoor et al., 2009; Lee et al., 2009; Holmes et al., 2011; Myhre et al., 2011; Unger, 2011; Frömming et al., 2012; Unger et al., 2013; Khodayari et al., 2014). This can be attributed to our model's lower OPE of 1.33 , in comparison to the range of 1-2.4 from other models (Myhre et al., 2011; Unger, 2011).

Our estimate of aviation-induced aCAE $\left[-23.6 \mathrm{~mW} \mathrm{~m}^{-2}\right]$ lies just outside the range provided by Gettelman and Chen (2013) and Righi et al. (2013) [-15.4 to $\left.-21 \mathrm{~mW} \mathrm{~m}^{-2}\right]$. Our estimated aDRE $\left[+1.4 \mathrm{~mW} \mathrm{~m}^{-2}\right]$ lies within the middle of the range given by previous work (Sausen et al., 2005; Fuglestvedt et al., 2008; Lee et al., 2009; Balkanski et al., 2010; Unger, 2011; Gettelman and Chen, 2013; Righi et al., 2013; Unger et al., 2013).

We estimate that standard aviation (NORM; $\mathrm{FSC}=600 \mathrm{ppm}$ ) is responsible for approximately 3600 premature mortalities annually due to increased surface layer $\mathrm{PM}_{2.5}$, in line with previous work (Barrett et al., 2012). We find that aviation-induced mortalities are highest over Europe, eastern North America and eastern China; reflecting larger regional perturbations in surface layer $\mathrm{PM}_{2.5}$ concentrations. Comparing these estimates with total global premature mortalities from ambient air pollution from all anthropogenic sources (Lim et al., 2012), aviation is responsible for $0.1 \%$ [0.04-0.18\%] of annual premature mortalities.

We investigated the impact of varying aviation FSC over the range 0-6000 ppm. Increases in FSC lead to increases in surface $\mathrm{PM}_{2.5}$ concentrations and subsequent increases in aviation-induced mortality. Increases in FSC also lead to a more negative $\mathrm{RE}_{\text {comb }}$ due to enhanced aCAEs. We estimate that the use of ultra-low sulfur jet (ULSJ) fuel, with a FSC of $15 \mathrm{ppm}$, could prevent 620 [230-1020] mortalities annually compared to standard aviation emissions. Swapping to ULSJ fuel increases the global mean net RE by $+7.0 \mathrm{~mW} \mathrm{~m}^{-2}$ compared to standard aviation emissions, largely due to a reduced aCAE. We calculate a larger warming effect from switching to ULSJ fuel than that assessed by Barrett et al. (2012), who did not evaluate changes in aCAE.

Absolute reductions in FSC result in limited reductions in aviation-induced surface layer $\mathrm{PM}_{2.5}$. We estimate that aviation- $\mathrm{NO}_{x}$ emissions are responsible for $36.2 \%$ of aviation-induced sulfate perturbations. Thus further reductions in aviation-induced $\mathrm{PM}_{2.5}$ can potentially be achieved if $\mathrm{NO}_{x}$ emission reductions are implemented in tandem with reductions to fuel sulfur content.

In line with previous work (Köhler et al., 2008; Stevenson and Derwent, 2009; Snijders and Melkers, 2011; Frömming et al., 2012; Skowron et al., 2013), decreasing the altitude at which $\mathrm{O}_{3}$-forming species are emitted results in a reduction in aviation-induced $\mathrm{O}_{3}$, and resulting O3DRE. This is due to the relationship between altitude and OPE, and the inverse relationship between altitude and background pollutant concentrations. We also explored the sensitivity of emission injection altitude on aerosol, mortality and aerosol RE. Injecting aviation emissions at the surface results in a reduction in global mean concentrations of $\mathrm{PM}_{2.5}$ (relative to NORM), but with higher regional concentrations over central Europe and eastern America; resulting in higher annual mortalities due to aviation. We find that aviation emissions are a factor of 5 less efficient at creating $\mathrm{CCN}$ when released at the surface, resulting in an aCAE of $-2.3 \mathrm{~mW} \mathrm{~m}^{-2}$, a reduction of $90.1 \%$ in relation to the standard aviation scenario. When aviation $\mathrm{SO}_{2}$ emissions are injected into the free-troposphere, the dominant oxidation pathway is to $\mathrm{H}_{2} \mathrm{SO}_{4}$ followed by particle formation and condensational growth of new particles to larger sizes. Subsequent entrainment of these new particles into the lower atmosphere leads to increased $\mathrm{CCN}$ concentrations and impacts on cloud albedo. Aviation $\mathrm{SO}_{2}$ emissions are therefore particularly efficient at forming $\mathrm{CCN}$ with resulting impacts on cloud albedo.

We explored the impact of applying altitude-dependent variations in aviation FSC. We tested a scenario with high FSC in the free troposphere and low FSC near the surface, resulting in the same global aviation sulfur emission as the standard aviation scenario. In this scenario, aviation-induced premature mortalities were reduced by $2.4 \%$ [ -90 mortalities $\mathrm{a}^{-1}$ ] and the magnitude of the negative $\mathrm{RE}_{\text {comb }}$ was increased by $36.6 \%$, providing an additional cooling impact of climate of $-4.88 \mathrm{~mW} \mathrm{~m}^{-2}$.

Our simulations suggest that the climate and air quality impacts of aviation are sensitive to FSC and the altitude of emissions. We explored a range of scenarios to maximise climate cooling and reduce air quality impacts. Use of ULSJ fuel $(\mathrm{FSC}=15 \mathrm{ppm})$ at low altitude combined with high FSC in the free troposphere results in increased climate cooling whilst reducing aviation mortality. More complicated emission patterns, for example, use of high FSC only whilst over oceans might further enhance this effect. However, we note that the greatest reduction in aviation-induced mortality is simulated for complete desulfurization of aviation fuel. Given the uncertainty in both the climate and air quality impacts of aerosol and ozone, additional simulations from a range of atmospheric models are required to explore the robustness of our calculations. Finally, we note that our calculations are limited to calculation of aviation-induced RE. Future work needs to assess the complex climate impacts of altering aviation FSC. Future work needs to estimate the health impacts of aviation using newly available concentration response functions (Burnett et al., 2014).

\section{Data availability}

Ozone observations used in this work can be acquired from Tilmes et al. (2012). Aerosol data are described in 
Heald et al. (2011). CMIP5 aviation emissions are available from http://tntcat.iiasa.ac.at:8787/RcpDb/dsd?Action= htmlpage\&page $=$ about. Model outputs are available on request from the corresponding author.

\section{The Supplement related to this article is available online at doi:10.5194/acp-16-10521-2016-supplement.}

Acknowledgements. The authors acknowledge the Engineering \& Physical Sciences Research Council (EPSRC) for funding of Z. Z. Kapadia through the EPSRC Doctoral Training Centre in Low Carbon Technologies (EPSRC Grant EP/G036608/1).

This work was undertaken on ARC2 as part of the High Performance Computing facilities at the University of Leeds, UK.

The authors are also grateful to Jean-Francois Lamarque and the "Historical emissions group" and IIASA for their publicly available recommended historical CMIP5 aviation emissions data.

Edited by: J. West

Reviewed by: two anonymous referees

\section{References}

Anderson, B. E., Chen, G., and Blake, D. R.: Hydrocarbon emissions from a modern commercial airliner, Atmos. Environ., 40, 3601-3612, doi:10.1016/j.atmosenv.2005.09.072, 2006.

Andres, R. J. and Kasgnoc, A. D.: A time-averaged inventory of subaerial volcanic sulfur emissions, J. Geophys. Res.-Atmos., 103, 25251-25261, doi:10.1029/98JD02091, 1998.

Arnold, S. R., Chipperfield, M. P., and Blitz, M. A.: A threedimensional model study of the effect of new temperaturedependent quantum yields for acetone photolysis, J. Geophys. Res.-Atmos., 110, D22305, doi:10.1029/2005JD005998, 2005.

ASTM International: D1655-11b: Standard Specification for Aviation Turbine Fuels, ASTM International, West Conshohocken, PA, USA, 2012.

Balkanski, Y., Myhre, G., Gauss, M., Rädel, G., Highwood, E. J., and Shine, K. P.: Direct radiative effect of aerosols emitted by transport: from road, shipping and aviation, Atmos. Chem. Phys., 10, 4477-4489, doi:10.5194/acp-10-4477-2010, 2010.

Barahona, D., West, R. E. L., Stier, P., Romakkaniemi, S., Kokkola, H., and Nenes, A.: Comprehensively accounting for the effect of giant $\mathrm{CCN}$ in cloud activation parameterizations, Atmos. Chem. Phys., 10, 2467-2473, doi:10.5194/acp-10-2467-2010, 2010.

Barrett, S. R. H., Britter, R. E., and Waitz, I. A.: Global Mortality Attributable to Aircraft Cruise Emissions, Environ. Sci. Technol., 44, 7736-7742, doi:10.1021/es101325r, 2010.

Barrett, S. R. H., Yim, S. H. L., Gilmore, C. K., Murray, L. T., Kuhn, S. R., Tai, A. P. K., Yantosca, R. M., Byun, D. W., Ngan, F., Li, X., Levy, J. I., Ashok, A., Koo, J., Wong, H. M., Dessens, O., Balasubramanian, S., Fleming, G. G., Pearlson, M. N., Wollersheim, C., Malina, R., Arunachalam, S., Binkowski, F. S., Leibensperger, E. M., Jacob, D. J., Hileman, J. I., and Waitz, I. A.: Public Health, Climate, and Economic Impacts of
Desulfurizing Jet Fuel, Environ. Sci. Technol., 46, 4275-4282, doi:10.1021/es203325a, 2012.

Benduhn, F., Mann, G. W., Pringle, K. J., Topping, D. O., McFiggans, G., and Carslaw, K. S.: Size-resolved simulations of the aerosol inorganic composition with the new hybrid dissolution solver HyDiS-1.0 - Description, evaluation and first global modelling results, Geosci. Model Dev. Discuss., doi:10.5194/gmd2015-264, in review, 2016.

Bond, T. C., Streets, D. G., Yarber, K. F., Nelson, S. M., Woo, J.-H., and Klimont, Z.: A technology-based global inventory of black and organic carbon emissions from combustion, J. Geophys. Res.-Atmos., 109, D14203, doi:10.1029/2003JD003697, 2004.

Bouwman, A. F., Lee, D. S., Asman, W. A. H., Dentener, F. J., Van Der Hoek, K. W., and Olivier, J. G. J.: A global high-resolution emission inventory for ammonia, Global Biogeochem. Cy., 11, 561-587, doi:10.1029/97GB02266, 1997.

Brasseur, G. P., Gupta, M., Anderson, B. E., Balasubramanian, S., Barrett, S., Duda, D., Fleming, G., Forster, P. M., Fuglestvedt, J., and Gettelman, A.: Impact of Aviation on Climate: FAA's Aviation Climate Change Research Initiative (ACCRI) Phase II, B. Am. Meteorol. Soc., 97, 561-583, 2016.

Breider, T. J., Chipperfield, M. P., Richards, N. A. D., Carslaw, K. S., Mann, G. W., and Spracklen, D. V.: Impact of BrO on dimethylsulfide in the remote marine boundary layer, Geophys. Res. Lett., 37, L02807, doi:10.1029/2009GL040868, 2010.

Burkhardt, U. and Karcher, B.: Global radiative forcing from contrail cirrus, Nature Clim. Change, 1, 54-58, 2011.

Burnett, R. T., Pope, C. A., Ezzati, M., Olives, C., Lim, S. S., Mehta, S., Shin, H. H., Singh, G., Hubbell, B., Brauer, M., Anderson, H. R., Smith, K. R., Balmes, J. R., Bruce, N. G., Kan, H. D., Laden, F., Pruss-Ustun, A., Michelle, C. T., Gapstur, S. M., Diver, W. R., and Cohen, A.: An Integrated Risk Function for Estimating the Global Burden of Disease Attributable to Ambient Fine Particulate Matter Exposure, Environ. Heal. Persp., 122, 397-403, doi:10.1289/ehp.1307049, 2014.

Chipperfield, M. P.: New version of the TOMCAT/SLIMCAT offline chemical transport model: Intercomparison of stratospheric tracer experiments, Q. J. Roy. Meteor. Soc., 132, 1179-1203, doi:10.1256/qj.05.51, 2006.

Chipperfield, M. P., Dhomse, S. S., Feng, W., McKenzie, R. L., Velders, G. J. M., and Pyle, J. A.: Quantifying the ozone and ultraviolet benefits already achieved by the Montreal Protocol, Nat. Commun., 6, 7233, doi:10.1038/ncomms8233, 2015.

Cofala, J., Amann, M., Klimont, Z., and Schopp, W.: Scenarios of World Anthropogenic Emissions of $\mathrm{SO}_{2}, \mathrm{NO}_{x}$ and $\mathrm{CO}$ up to 2030, International Institute for Applied Systems Analysis, Laxenburg, Austria, 2005.

Dentener, F., Kinne, S., Bond, T., Boucher, O., Cofala, J., Generoso, S., Ginoux, P., Gong, S., Hoelzemann, J. J., Ito, A., Marelli, L., Penner, J. E., Putaud, J.-P., Textor, C., Schulz, M., van der Werf, G. R., and Wilson, J.: Emissions of primary aerosol and precursor gases in the years 2000 and 1750 prescribed data-sets for AeroCom, Atmos. Chem. Phys., 6, 4321-4344, doi:10.5194/acp-64321-2006, 2006.

Dessens, O., Köhler, M. O., Rogers, H. L., Jones, R. L., and Pyle, J. A.: Aviation and climate change, Transp. Policy, 34, 14-20, doi:10.1016/j.tranpol.2014.02.014, 2014. 
Dockery, D. W., Pope, C. A., Xu, X., Spengler, J. D., Ware, J. H., Fay, M. E., Ferris, B. G., and Speizer, F. E.: An Association between Air Pollution and Mortality in Six U.S. Cities, New Engl. J. Med., 329, 1753-1759, doi:10.1056/NEJM199312093292401, 1993.

DuBois, D. and Paynter, G. C.: "Fuel Flow Method2" for Estimating Aircraft Emissions, SAE Technical Paper Series, 01, 2006.

Eckhardt, S., Quennehen, B., Olivié, D. J. L., Berntsen, T. K., Cherian, R., Christensen, J. H., Collins, W., Crepinsek, S., Daskalakis, N., Flanner, M., Herber, A., Heyes, C., Hodnebrog, Ø., Huang, L., Kanakidou, M., Klimont, Z., Langner, J., Law, K. S., Lund, M. T., Mahmood, R., Massling, A., Myriokefalitakis, S., Nielsen, I. E., Nøjgaard, J. K., Quaas, J., Quinn, P. K., Raut, J.-C., Rumbold, S. T., Schulz, M., Sharma, S., Skeie, R. B., Skov, H., Uttal, T., von Salzen, K., and Stohl, A.: Current model capabilities for simulating black carbon and sulfate concentrations in the Arctic atmosphere: a multi-model evaluation using a comprehensive measurement data set, Atmos. Chem. Phys., 15, 9413-9433, doi:10.5194/acp-15-9413-2015, 2015.

Edwards, J. M. and Slingo, A.: Studies with a flexible new radiation code. I: Choosing a configuration for a large-scale model, Q. J. Roy. Meteor. Soc., 122, 689-719, doi:10.1002/qj.49712253107, 1996.

Eyers, C. J., Addleton, D., Atkinson, K., Broomhead, M. J., Christou, R., Elliff, T., Falk, R., Gee, I., Lee, D. S., Marizy, C., S Michot, Middel, J., Newton, P., Norman, P., Plohr, M., Raper, D., and Stanciou, N.: AERO2K Global Aviation Emissions Inventories for 2002 and 2025, QINETIQ/04/01113, 2004.

Eyring, V., Isaksen, I. S. A., Berntsen, T., Collins, W. J., Corbett, J. J., Endresen, O., Grainger, R. G., Moldanova, J., Schlager, H., and Stevenson, D. S.: Transport impacts on atmosphere and climate: Shipping, Atmos. Environ., 44, 4735-4771, doi:10.1016/j.atmosenv.2009.04.059, 2010.

Fiore, A. M., Naik, V., Spracklen, D. V., Steiner, A., Unger, N., Prather, M., Bergmann, D., Cameron-Smith, P. J., Cionni, I., Collins, W. J., Dalsoren, S., Eyring, V., Folberth, G. A., Ginoux, P., Horowitz, L. W., Josse, B., Lamarque, J.-F., MacKenzie, I. A., Nagashima, T., O’Connor, F. M., Righi, M., Rumbold, S. T., Shindell, D. T., Skeie, R. B., Sudo, K., Szopa, S., Takemura, T., and Zeng, G.: Global air quality and climate, Chem. Soc. Rev., 41, 6663-6683, 2012.

Fountoukis, C. and Nenes, A.: Continued development of a cloud droplet formation parameterization for global climate models, J. Geophys. Res.-Atmos., 110, D11212, doi:10.1029/2004JD005591, 2005.

Frömming, C., Ponater, M., Dahlmann, K., Grewe, V., Lee, D. S., and Sausen, R.: Aviation-induced radiative forcing and surface temperature change in dependency of the emission altitude, J. Geophys. Res., 117, D19104, doi:10.1029/2012JD018204, 2012.

Fuglestvedt, J., Berntsen, T., Myhre, G., Rypdal, K., and Skeie, R. B.: Climate forcing from the transport sectors, P. Natl. Acad. Sci., 105, 454-458, doi:10.1073/pnas.0702958104, 2008.

Gettelman, A. and Chen, C.: The climate impact of aviation aerosols, Geophys. Res. Lett., 40, 2785-2789, doi:10.1002/grl.50520, 2013.

Guenther, A., Hewitt, C. N., Erickson, D., Fall, R., Geron, C., Graedel, T., Harley, P., Klinger, L., Lerdau, M., McKay, W. A., Pierce, T., Scholes, B., Steinbrecher, R., Tallamraju, R., Taylor, J., and Zimmerman, P.: A global model of natural volatile organic compound emissions, J. Geophys. Res.-Atmos., 100, 8873-8892, doi:10.1029/94JD02950, 1995.

Halmer, M. M., Schmincke, H. U., and Graf, H. F.: The annual volcanic gas input into the atmosphere, in particular into the stratosphere: a global data set for the past 100 years, J. Volcanol. Geoth. Res., 115, 511-528, doi:10.1016/S0377-0273(01)003183, 2002 .

Hand, J. L., Schichtel, B. A., Malm, W. C., and Pitchford, M. L.: Particulate sulfate ion concentration and $\mathrm{SO}_{2}$ emission trends in the United States from the early 1990s through 2010, Atmos. Chem. Phys., 12, 10353-10365, doi:10.5194/acp-1210353-2012, 2012.

Heald, C. L., Coe, H., Jimenez, J. L., Weber, R. J., Bahreini, R., Middlebrook, A. M., Russell, L. M., Jolleys, M., Fu, T.-M., Allan, J. D., Bower, K. N., Capes, G., Crosier, J., Morgan, W. T., Robinson, N. H., Williams, P. I., Cubison, M. J., DeCarlo, P. F., and Dunlea, E. J.: Exploring the vertical profile of atmospheric organic aerosol: comparing 17 aircraft field campaigns with a global model, Atmos. Chem. Phys., 11, 12673-12696, doi:10.5194/acp-11-12673-2011, 2011.

Hileman, J. I. and Stratton, R. W.: Alternative jet fuel feasibility, Transp. Policy, 34, 52-62, doi:10.1016/j.tranpol.2014.02.018, 2014.

Holmes, C. D., Tang, Q., and Prather, M. J.: Uncertainties in climate assessment for the case of aviation NO, P. Natl. Acad. Sci., 108, 10997-11002, doi:10.1073/pnas.1101458108, 2011.

Hoor, P., Borken-Kleefeld, J., Caro, D., Dessens, O., Endresen, O., Gauss, M., Grewe, V., Hauglustaine, D., Isaksen, I. S. A., Jöckel, P., Lelieveld, J., Myhre, G., Meijer, E., Olivie, D., Prather, M., Schnadt Poberaj, C., Shine, K. P., Staehelin, J., Tang, Q., van Aardenne, J., van Velthoven, P., and Sausen, R.: The impact of traffic emissions on atmospheric ozone and $\mathrm{OH}$ : results from QUANTIFY, Atmos. Chem. Phys., 9, 3113-3136, doi:10.5194/acp-9-3113-2009, 2009.

Hopke, P. K.: Receptor modeling in environmental chemistry, Chemical Analysis: A Series of Monographs on Analytical Chemistry and Its Applications, Wiley, Hoboken, N. J., 1985.

ICAO: Annual Report of the Council 2012, International Civil Aviation Organisation (ICAO), 2013.

Jacobson, M. Z., Wilkerson, J. T., Naiman, A. D., and Lele, S. K.: The effects of aircraft on climate and pollution. Part II: 20year impacts of exhaust from all commercial aircraft worldwide treated individually at the subgrid scale, Faraday Discuss., 165, 369-382, doi:10.1039/C3FD00034F, 2013.

Kaiser, J. W., Heil, A., Andreae, M. O., Benedetti, A., Chubarova, N., Jones, L., Morcrette, J.-J., Razinger, M., Schultz, M. G., Suttie, M., and van der Werf, G. R.: Biomass burning emissions estimated with a global fire assimilation system based on observed fire radiative power, Biogeosciences, 9, 527-554, doi:10.5194/bg-9-527-2012, 2012.

Kettle, A. J. and Andreae, M. O.: Flux of dimethylsulfide from the oceans: A comparison of updated data sets and flux models, J. Geophys. Res.-Atmos., 105, 26793-26808, doi:10.1029/2000JD900252, 2000.

Khodayari, A., Olsen, S. C., and Wuebbles, D. J.: Evaluation of aviation $\mathrm{NO}_{x}$-induced radiative forcings for 2005 and 2050, Atmos. Environ., 91, 95-103, doi:10.1016/j.atmosenv.2014.03.044, 2014. 
Knighton, W. B., Rogers, T. M., Anderson, B. E., Herndon, S. C., Yelvington, P. E., and Miake-Lye, R. C.: Quantification of Aircraft Engine Hydrocarbon Emissions Using Proton Transfer Reaction Mass Spectrometry, J. Propul. Power, 23, 949-958, 2007.

Knippertz, P., Evans, M. J., Field, P. R., Fink, A. H., Liousse, C., and Marsham, J. H.: The possible role of local air pollution in climate change in West Africa, Nature Clim. Change, 5, 815822, doi:10.1038/nclimate2727, 2015.

Köhler, M. O., Rädel, G., Dessens, O., Shine, K. P., Rogers, H. L., Wild, O., and Pyle, J. A.: Impact of perturbations to nitrogen oxide emissions from global aviation, J. Geophys. Res.-Atmos., 113, D11305, doi:10.1029/2007JD009140, 2008.

Köhler, M. O., Rädel, G., Shine, K. P., Rogers, H. L., and Pyle, J. A.: Latitudinal variation of the effect of aviation $\mathrm{NO}_{x}$ emissions on atmospheric ozone and methane and related climate metrics, Atmos. Environ., 64, 1-9, doi:10.1016/j.atmosenv.2012.09.013, 2013.

Konovalov, I. B., Beekmann, M., Burrows, J. P., and Richter, A.: Satellite measurement based estimates of decadal changes in European nitrogen oxides emissions, Atmos. Chem. Phys., 8, $2623-$ 2641, doi:10.5194/acp-8-2623-2008, 2008.

Lamarque, J.-F., Hess, P., Emmons, L., Buja, L., Washington, W., and Granier, C.: Tropospheric ozone evolution between 1890 and 1990, J. Geophys. Res.-Atmos., 110, D08304, doi:10.1029/2004JD005537, 2005.

Lamarque, J.-F., Smith, S. J., Bond, T., Cofala, J., Eyring, V., Granier, C., Heil, A., Kainuma, M., Klimont, Z., Lee, D., Liousse, C., Mieville, A., Riahi, K., Schultz, M., Stevenson, D., Van Aardenne, J., and van Vuuren, D.: RCP Database (Version 2.0.5): Historical emissions data (1850-2000), International Institute for Applied Systems Analysis, in: International Institute for Applied Systems Analysis, RCP Database, 2009.

Lamarque, J.-F., Bond, T. C., Eyring, V., Granier, C., Heil, A., Klimont, Z., Lee, D., Liousse, C., Mieville, A., Owen, B., Schultz, M. G., Shindell, D., Smith, S. J., Stehfest, E., Van Aardenne, J., Cooper, O. R., Kainuma, M., Mahowald, N., McConnell, J. R., Naik, V., Riahi, K., and van Vuuren, D. P.: Historical (1850-2000) gridded anthropogenic and biomass burning emissions of reactive gases and aerosols: methodology and application, Atmos. Chem. Phys., 10, 7017-7039, doi:10.5194/acp10-7017-2010, 2010.

Lee, D. S., Fahey, D. W., Forster, P. M., Newton, P. J., Wit, R. C. N., Lim, L. L., Owen, B., and Sausen, R.: Aviation and global climate change in the 21st century, Atmos. Environ., 43, 35203537, doi:10.1016/j.atmosenv.2009.04.024, 2009.

Lee, D. S., Pitari, G., Grewe, V., Gierens, K., Penner, J. E., Petzold, A., Prather, M. J., Schumann, U., Bais, A., Berntsen, T., Iachetti, D., Lim, L. L., and Sausen, R.: Transport impacts on atmosphere and climate: Aviation, Atmos. Environ., 44, 46784734, doi:10.1016/j.atmosenv.2009.06.005, 2010.

Lim, S. S., Vos, T., Flaxman, A. D., Danaei, G., Shibuya, K., AdairRohani, H., AlMazroa, M. A., Amann, M., Anderson, H. R., Andrews, K. G., Aryee, M., Atkinson, C., Bacchus, L. J., Bahalim, A. N., Balakrishnan, K., Balmes, J., Barker-Collo, S., Baxter, A., Bell, M. L., Blore, J. D., Blyth, F., Bonner, C., Borges, G., Bourne, R., Boussinesq, M., Brauer, M., Brooks, P., Bruce, N. G., Brunekreef, B., Bryan-Hancock, C., Bucello, C., Buchbinder, R., Bull, F., Burnett, R. T., Byers, T. E., Calabria, B., Carapetis, J., Carnahan, E., Chafe, Z., Charlson, F., Chen, H., Chen, J. S.,
Cheng, A. T.-A., Child, J. C., Cohen, A., Colson, K. E., Cowie, B. C., Darby, S., Darling, S., Davis, A., Degenhardt, L., Dentener, F., Des Jarlais, D. C., Devries, K., Dherani, M., Ding, E. L., Dorsey, E. R., Driscoll, T., Edmond, K., Ali, S. E., Engell, R. E., Erwin, P. J., Fahimi, S., Falder, G., Farzadfar, F., Ferrari, A., Finucane, M. M., Flaxman, S., Fowkes, F. G. R., Freedman, G., Freeman, M. K., Gakidou, E., Ghosh, S., Giovannucci, E., Gmel, G., Graham, K., Grainger, R., Grant, B., Gunnell, D., Gutierrez, H. R., Hall, W., Hoek, H. W., Hogan, A., Hosgood Iii, H. D., Hoy, D., Hu, H., Hubbell, B. J., Hutchings, S. J., Ibeanusi, S. E., Jacklyn, G. L., Jasrasaria, R., Jonas, J. B., Kan, H., Kanis, J. A., Kassebaum, N., Kawakami, N., Khang, Y.-H., Khatibzadeh, S., Khoo, J.-P., Kok, C., Laden, F., Lalloo, R., Lan, Q., Lathlean, T., Leasher, J. L., Leigh, J., Li, Y., Lin, J. K., Lipshultz, S. E., London, S., Lozano, R., Lu, Y., Mak, J., Malekzadeh, R., Mallinger, L., Marcenes, W., March, L., Marks, R., Martin, R., McGale, P., McGrath, J., Mehta, S., Memish, Z. A., Mensah, G. A., Merriman, T. R., Micha, R., Michaud, C., Mishra, V., Hanafiah, K. M., Mokdad, A. A., Morawska, L., Mozaffarian, D., Murphy, T., Naghavi, M., Neal, B., Nelson, P. K., Nolla, J. M., Norman, R., Olives, C., Omer, S. B., Orchard, J., Osborne, R., Ostro, B., Page, A., Pandey, K. D., Parry, C. D. H., Passmore, E., Patra, J., Pearce, N., Pelizzari, P. M., Petzold, M., Phillips, M. R., Pope, D., Pope III, C. A., Powles, J., Rao, M., Razavi, H., Rehfuess, E. A., Rehm, J. T., Ritz, B., Rivara, F. P., Roberts, T., Robinson, C., Rodriguez-Portales, J. A., Romieu, I., Room, R., Rosenfeld, L. C., Roy, A., Rushton, L., Salomon, J. A., Sampson, U., SanchezRiera, L., Sanman, E., Sapkota, A., Seedat, S., Shi, P., Shield, K., Shivakoti, R., Singh, G. M., Sleet, D. A., Smith, E., Smith, K. R., Stapelberg, N. J. C., Steenland, K., Stöckl, H., Stovner, L. J., Straif, K., Straney, L., Thurston, G. D., Tran, J. H., Van Dingenen, R., van Donkelaar, A., Veerman, J. L., Vijayakumar, L., Weintraub, R., Weissman, M. M., White, R. A., Whiteford, H., Wiersma, S. T., Wilkinson, J. D., Williams, H. C., Williams, W., Wilson, N., Woolf, A. D., Yip, P., Zielinski, J. M., Lopez, A. D., Murray, C. J. L., and Ezzati, M.: A comparative risk assessment of burden of disease and injury attributable to 67 risk factors and risk factor clusters in 21 regions, 1990-2010: a systematic analysis for the Global Burden of Disease Study 2010, The Lancet 380, 2224-2260, doi:10.1016/S0140-6736(12)61766-8, 2012.

Mann, G. W., Carslaw, K. S., Spracklen, D. V., Ridley, D. A., Manktelow, P. T., Chipperfield, M. P., Pickering, S. J., and Johnson, C. E.: Description and evaluation of GLOMAP-mode: a modal global aerosol microphysics model for the UKCA composition-climate model, Geosci. Model Dev., 3, 519-551, doi:10.5194/gmd-3-519-2010, 2010.

Ministry of Defence: Defence Standard 91-91, Turbine Fuel, Kerosine Type, Jet A-1. NATO Code: F-35, Joint Service Designation: AVTUR, Glasgow, United Kingdom, 2011.

Morita, H., Yang, S., Unger, N., and Kinney, P. L.: Global Health Impacts of Future Aviation Emissions Under Alternative Control Scenarios, Environ. Sci. Technol., 48, 14659-14667, doi:10.1021/es5055379, 2014.

Myhre, G., Shine, K. P., Rädel, G., Gauss, M., Isaksen, I. S. A., Tang, Q., Prather, M. J., Williams, J. E., van Velthoven, P., Dessens, O., Koffi, B., Szopa, S., Hoor, P., Grewe, V., Borken-Kleefeld, J., Berntsen, T. K., and Fuglestvedt, J. S.: Radiative forcing due to changes in ozone and methane 
caused by the transport sector, Atmos. Environ., 45, 387-394, doi:10.1016/j.atmosenv.2010.10.001, 2011.

Nenes, A. and Seinfeld, J. H.: Parameterization of cloud droplet formation in global climate models, J. Geophys. Res.-Atmos., 108, 4415, doi:10.1029/2002JD002911, 2003.

Nightingale, P. D., Malin, G., Law, C. S., Watson, A. J., Liss, P. S., Liddicoat, M. I., Boutin, J., and Upstill-Goddard, R. C.: In situ evaluation of air-sea gas exchange parameterizations using novel conservative and volatile tracers, Global Biogeochem. Cy., 14, 373-387, doi:10.1029/1999GB900091, 2000.

Olsen, S. C., Wuebbles, D. J., and Owen, B.: Comparison of global 3-D aviation emissions datasets, Atmos. Chem. Phys., 13, 429441, doi:10.5194/acp-13-429-2013, 2013.

Ostro, B. D.: Outdoor air pollution: Assessing the environmental burden of disease at national and local levels, WHO Environmental Burden of Disease Series, No. 5, Geneva, Switzerland, 2004.

Pope, C. A. and Dockery, D. W.: Health effects of fine particulate air pollution: lines that connect, J. Air Waste Manage., 56, 709-742, 2006.

Pope, C. A., Burnett, R. T., Thun, M. J., Calle, E. E., Krewski, D., Ito, K., and Thurston, G. D.: Lung Cancer, Cardiopulmonary Mortality, and Long-term Exposure to Fine Particulate Air Pollution, JAMA, 287, 1132-1141, doi:10.1001/jama.287.9.1132, 2002.

EU FP6 Integrated Project QUANTIFY: Quantifying the Climate Impact of Global and European Transport Systems: QUANTIFY emission inventories and scenarios: http://www.pa.op.dlr. de/quantify/ (last access: 15 July 2011), 2005-2012.

Rap, A., Forster, P. M., Jones, A., Boucher, O., Haywood, J. M., Bellouin, N., and De Leon, R. R.: Parameterization of contrails in the UK Met Office Climate Model, J. Geophys. Res., 115, D10205, doi:10.1029/2009jd012443, 2010.

Rap, A., Scott, C. E., Spracklen, D. V., Bellouin, N., Forster, P. M., Carslaw, K. S., Schmidt, A., and Mann, G.: Natural aerosol direct and indirect radiative effects, Geophys. Res. Lett., 40, 32973301, doi:10.1002/grl.50441, 2013.

Rap, A., Richards, N. A. D., Forster, P. M., Monks, S. A., Arnold, S. R., and Chipperfield, M. P.: Satellite constraint on the tropospheric ozone radiative effect, Geophys. Res. Lett., 42, 50745081, doi:10.1002/2015GL064037, 2015.

Ratliff, G., Sequeira, C., Waitz, I., Ohsfeldt, M., Thrasher, T., Graham, M., and Thompson, T.: Aircraft Impacts on Local and Regional Air Quality in the United States, Massachusetts Institute of Technology, PARTNER report (Report No. PARTNER-COE2009-002), 2009.

Richards, N. A. D., Arnold, S. R., Chipperfield, M. P., Miles, G., Rap, A., Siddans, R., Monks, S. A., and Hollaway, M. J.: The Mediterranean summertime ozone maximum: global emission sensitivities and radiative impacts, Atmos. Chem. Phys., 13, 2331-2345, doi:10.5194/acp-13-2331-2013, 2013.

Righi, M., Hendricks, J., and Sausen, R.: The global impact of the transport sectors on atmospheric aerosol: simulations for year 2000 emissions, Atmos. Chem. Phys., 13, 9939-9970, doi:10.5194/acp-13-9939-2013, 2013.

Rossow, W. B. and Schiffer, R. A.: Advances in Understanding Clouds from ISCCP, B. Am. Meteorol. Soc., 80, 2261-2287, doi:10.1175/1520-0477(1999)080<2261:AIUCFI>2.0.CO;2, 1999.
Sausen, R., Isaksen, I., Grewe, V., Hauglustaine, D., Lee, D. S., Myhre, G., Köhler, M. O., Pitari, G., Schumann, U., Stordal, F., and Zerefos, C.: Aviation radiative forcing in 2000: An update on IPCC (1999), Meteorol. Z., 14, 555-561, 2005.

Schmidt, A., Carslaw, K. S., Mann, G. W., Rap, A., Pringle, K. J., Spracklen, D. V., Wilson, M., and Forster, P. M.: Importance of tropospheric volcanic aerosol for indirect radiative forcing of climate, Atmos. Chem. Phys., 12, 7321-7339, doi:10.5194/acp-127321-2012, 2012.

Shindell, D. T., Chin, M., Dentener, F., Doherty, R. M., Faluvegi, G., Fiore, A. M., Hess, P., Koch, D. M., MacKenzie, I. A., Sanderson, M. G., Schultz, M. G., Schulz, M., Stevenson, D. S., Teich, H., Textor, C., Wild, O., Bergmann, D. J., Bey, I., Bian, H., Cuvelier, C., Duncan, B. N., Folberth, G., Horowitz, L. W., Jonson, J., Kaminski, J. W., Marmer, E., Park, R., Pringle, K. J., Schroeder, S., Szopa, S., Takemura, T., Zeng, G., Keating, T. J., and Zuber, A.: A multi-model assessment of pollution transport to the Arctic, Atmos. Chem. Phys., 8, 5353-5372, doi:10.5194/acp-85353-2008, 2008.

Skowron, A., Lee, D. S., and De León, R. R.: The assessment of the impact of aviation $\mathrm{NO}_{x}$ on ozone and other radiative forcing responses - The importance of representing cruise altitudes accurately, Atmos. Environ., 74, 159-168, doi:10.1016/j.atmosenv.2013.03.034, 2013.

Snijders, T. A. and Melkers, J. A.: Effect of cruise altitude and alternative aviation fuels on radiative forcing, in: 47th AIAA/ASME/SAE/ASEE Joint Propulsion Conference \& Exhibit, Joint Propulsion Conferences, American Institute of Aeronautics and Astronautics, 2011.

Spicer, C. W., Holdren, M. W., Riggin, R. M., and Lyon, T. F.: Chemical composition and photochemical reactivity of exhaust from aircraft turbine engines, Ann. Geophys., 12, 944-955, doi:10.1007/s00585-994-0944-0, 1994.

Spracklen, D. V., Pringle, K. J., Carslaw, K. S., Chipperfield, M. P., and Mann, G. W.: A global off-line model of sizeresolved aerosol microphysics: I. Model development and prediction of aerosol properties, Atmos. Chem. Phys., 5, 22272252, doi:10.5194/acp-5-2227-2005, 2005.

Spracklen, D. V., Carslaw, K. S., Merikanto, J., Mann, G. W., Reddington, C. L., Pickering, S., Ogren, J. A., Andrews, E., Baltensperger, U., Weingartner, E., Boy, M., Kulmala, M., Laakso, L., Lihavainen, H., Kivekäs, N., Komppula, M., Mihalopoulos, N., Kouvarakis, G., Jennings, S. G., O’Dowd, C., Birmili, W., Wiedensohler, A., Weller, R., Gras, J., Laj, P., Sellegri, K., Bonn, B., Krejci, R., Laaksonen, A., Hamed, A., Minikin, A., Harrison, R. M., Talbot, R., and Sun, J.: Explaining global surface aerosol number concentrations in terms of primary emissions and particle formation, Atmos. Chem. Phys., 10, 4775-4793, doi:10.5194/acp-10-4775-2010, 2010.

Spracklen, D. V., Carslaw, K. S., Pöschl, U., Rap, A., and Forster, P. M.: Global cloud condensation nuclei influenced by carbonaceous combustion aerosol, Atmos. Chem. Phys., 11, 9067-9087, doi:10.5194/acp-11-9067-2011, 2011a.

Spracklen, D. V., Jimenez, J. L., Carslaw, K. S., Worsnop, D. R., Evans, M. J., Mann, G. W., Zhang, Q., Canagaratna, M. R., Allan, J., Coe, H., McFiggans, G., Rap, A., and Forster, P.: Aerosol mass spectrometer constraint on the global secondary organic aerosol budget, Atmos. Chem. Phys., 11, 12109-12136, doi:10.5194/acp-11-12109-2011, 2011 b. 
Stevenson, D. S. and Derwent, R. G.: Does the location of aircraft nitrogen oxide emissions affect their climate impact?, Geophys. Res. Lett., 36, L17810, doi:10.1029/2009GL039422, 2009.

Stevenson, D. S., Young, P. J., Naik, V., Lamarque, J.-F., Shindell, D. T., Voulgarakis, A., Skeie, R. B., Dalsoren, S. B., Myhre, G., Berntsen, T. K., Folberth, G. A., Rumbold, S. T., Collins, W. J., MacKenzie, I. A., Doherty, R. M., Zeng, G., van Noije, T. P. C., Strunk, A., Bergmann, D., Cameron-Smith, P., Plummer, D. A., Strode, S. A., Horowitz, L., Lee, Y. H., Szopa, S., Sudo, K., Nagashima, T., Josse, B., Cionni, I., Righi, M., Eyring, V., Conley, A., Bowman, K. W., Wild, O., and Archibald, A.: Tropospheric ozone changes, radiative forcing and attribution to emissions in the Atmospheric Chemistry and Climate Model Intercomparison Project (ACCMIP), Atmos. Chem. Phys., 13, 3063-3085, doi:10.5194/acp-13-3063-2013, 2013.

Thompson, A. M., Tao, W.-K., Pickering, K. E., Scala, J. R., and Simpson, J.: Tropical Deep Convection and Ozone Formation, B. Am. Meteorol. Soc., 78, 1043-1054, doi:10.1175/15200477(1997)078<1043:TDCAOF>2.0.CO;2, 1997.

Tilmes, S., Lamarque, J.-F., Emmons, L. K., Conley, A., Schultz, M. G., Saunois, M., Thouret, V., Thompson, A. M., Oltmans, S. J., Johnson, B., and Tarasick, D.: Technical Note: Ozonesonde climatology between 1995 and 2011: description, evaluation and applications, Atmos. Chem. Phys., 12, 74757497, doi:10.5194/acp-12-7475-2012, 2012.

Uherek, E., Halenka, T., Borken-Kleefeld, J., Balkanski, Y., Berntsen, T., Borrego, C., Gauss, M., Hoor, P., Juda-Rezler, K., Lelieveld, J., Melas, D., Rypdal, K., and Schmid, S.: Transport impacts on atmosphere and climate: Land transport, Atmos. Environ., 44, 4772-4816, doi:10.1016/j.atmosenv.2010.01.002, 2010.

Unger, N.: Global climate impact of civil aviation for standard and desulfurized jet fuel, Geophys. Res. Lett., 38, L20803, doi:10.1029/2011g1049289, 2011.

Unger, N., Shindell, D. T., Koch, D. M., and Streets, D. G.: Cross influences of ozone and sulfate precursor emissions changes on air quality and climate, P. Natl. Acad. Sci. USA, 103, 4377-4380, doi:10.1073/pnas.0508769103, 2006.

Unger, N., Zhao, Y., and Dang, H.: Mid-21st century chemical forcing of climate by the civil aviation sector, Geophys. Res. Lett., 40, 641-645, doi:10.1002/grl.50161, 2013.

Van Der Werf, G. R., Randerson, J. T., Collatz, G. J., and Giglio, L.: Carbon emissions from fires in tropical and subtropical ecosystems, Glob. Change Biol., 9, 547-562, doi:10.1046/j.13652486.2003.00604.x, 2003.

van der Werf, G. R., Randerson, J. T., Giglio, L., Collatz, G. J., Mu, M., Kasibhatla, P. S., Morton, D. C., DeFries, R. S., Jin, Y., and van Leeuwen, T. T.: Global fire emissions and the contribution of deforestation, savanna, forest, agricultural, and peat fires (19972009), Atmos. Chem. Phys., 10, 11707-11735, doi:10.5194/acp10-11707-2010, 2010.

Vestreng, V., Myhre, G., Fagerli, H., Reis, S., and Tarrasón, L.: Twenty-five years of continuous sulphur dioxide emission reduction in Europe, Atmos. Chem. Phys., 7, 3663-3681, doi:10.5194/acp-7-3663-2007, 2007.
Wayson, R. L., Fleming, G. G., and Iovinelli, R.: Methodology to Estimate Particulate Matter Emissions from Certified Commercial Aircraft Engines, J. Air Waste Manage., 59, 91-100, doi:10.3155/1047-3289.59.1.91, 2009.

Whitburn, S., Van Damme, M., Kaiser, J. W., van der Werf, G. R., Turquety, S., Hurtmans, D., Clarisse, L., Clerbaux, C., and Coheur, P. F.: Ammonia emissions in tropical biomass burning regions: Comparison between satellite-derived emissions and bottom-up fire inventories, Atmos. Environ., doi:10.1016/j.atmosenv.2015.03.015, 2015.

Wiedinmyer, C., Akagi, S. K., Yokelson, R. J., Emmons, L. K., AlSaadi, J. A., Orlando, J. J., and Soja, A. J.: The Fire INventory from NCAR (FINN): a high resolution global model to estimate the emissions from open burning, Geosci. Model Dev., 4, 625641, doi:10.5194/gmd-4-625-2011, 2011.

Wilkerson, J. T., Jacobson, M. Z., Malwitz, A., Balasubramanian, S., Wayson, R., Fleming, G., Naiman, A. D., and Lele, S. K.: Analysis of emission data from global commercial aviation: 2004 and 2006, Atmos. Chem. Phys., 10, 6391-6408, doi:10.5194/acp-10-6391-2010, 2010.

Woody, M., Haeng Baek, B., Adelman, Z., Omary, M., Fat Lam, Y., Jason West, J., and Arunachalam, S.: An assessment of Aviation's contribution to current and future fine particulate matter in the United States, Atmos. Environ., 45, 3424-3433, doi:10.1016/j.atmosenv.2011.03.041, 2011.

World Health Organisation: Health Aspects of Air Pollution with Particulate Matter, Ozone and Nitrogen Dioxide, Bonn, Germany, 2003.

World Health Organisation: Air Quality Guidelines a Global Update 2005: Particulate matter, ozone, nitrogen dioxide and sulphur dioxide, Germany, 2005.

Yim, N.-H., Kim, S.-H., Kim, H.-W., and Kwahk, K.-Y.: Knowledge based decision making on higher level strategic concerns: system dynamics approach, Expert Syst. Appl., 27, 143-158, doi:10.1016/j.eswa.2003.12.019, 2004.

Yim, S. H. L., Lee, G. L., Lee, I. H., Allroggen, F., Ashok, A., Caiazzo, F., Eastham, S. D., Malina, R., and Barrett, S. R. H.: Global, regional and local health impacts of civil aviation emissions, Environ. Res. Lett., 10, 034001, doi:10.1088/17489326/10/3/034001, 2015.

Young, P. J., Archibald, A. T., Bowman, K. W., Lamarque, J.-F., Naik, V., Stevenson, D. S., Tilmes, S., Voulgarakis, A., Wild, O., Bergmann, D., Cameron-Smith, P., Cionni, I., Collins, W. J., Dalsøren, S. B., Doherty, R. M., Eyring, V., Faluvegi, G., Horowitz, L. W., Josse, B., Lee, Y. H., MacKenzie, I. A., Nagashima, T., Plummer, D. A., Righi, M., Rumbold, S. T., Skeie, R. B., Shindell, D. T., Strode, S. A., Sudo, K., Szopa, S., and Zeng, G.: Preindustrial to end 21 st century projections of tropospheric ozone from the Atmospheric Chemistry and Climate Model Intercomparison Project (ACCMIP), Atmos. Chem. Phys., 13, 2063 2090, doi:10.5194/acp-13-2063-2013, 2013. 